\title{
Información Importante
}

La Universidad Santo Tomás, informa que el(los) autor(es) ha(n) autorizado a usuarios internos y externos de la institución a consultar el contenido de este documento a través del Catálogo en línea de la Biblioteca y el Repositorio Institucional en la página Web de la Biblioteca, así como en las redes de información del país y del exterior con las cuales tenga convenio la Universidad.

Se permite la consulta a los usuarios interesados en el contenido de este documento, para todos los usos que tengan finalidad académica, nunca para usos comerciales, siempre y cuando mediante la correspondiente cita bibliográfica se le dé crédito al trabajo de grado y a su autor.

De conformidad con lo establecido en el Artículo 30 de la Ley 23 de 1982 y el artículo 11 de la Decisión Andina 351 de 1993, la Universidad Santo Tomás informa que "los derechos morales sobre documento son propiedad de los autores, los cuales son irrenunciables, imprescriptibles, inembargables e inalienables."

\section{Bibliotecas Bucaramanga Universidad Santo Tomás}


Análisis del estatuto único de rentas del municipio de Pamplona en relación a las tarifas, exenciones, y estímulos de los impuestos predial e industria y comercio, avisos y tableros comparado con tres municipio Pamplona Tunja y Ocaña

\author{
Rosa Adelaida Parada Peláez \\ Mayra Melissa Hernández \\ Maria Gladys Parada Niño \\ Jorge Pinilla Cruz
}

Trabajo de grado para optar al título de Especialista en Gerencia Tributaria

\author{
Asesor: \\ Dr., Mario E. Serrano Rodríguez
}

Universidad Santo Tomas

Especialización Gerencia Tributaria

Bucaramanga 


\section{Contenido}

Introducción

1. Análisis del estatuto único de rentas del Municipio de Pamplona en relación a las tarifas, exenciones, y estímulos de los impuestos predial e industria y comercio, avisos y tableros y comparado con tres municipio Pamplona Tunja y Ocaña.

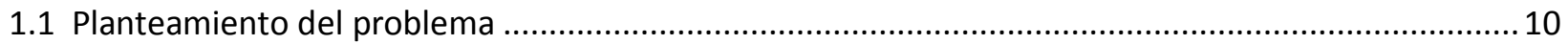

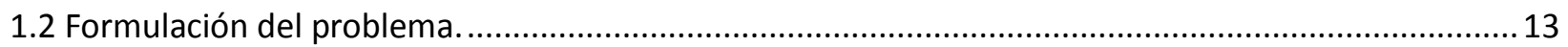

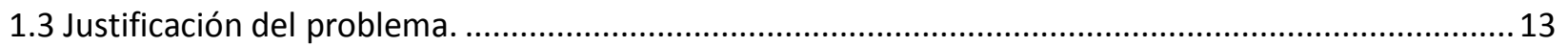

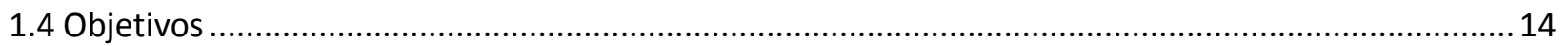

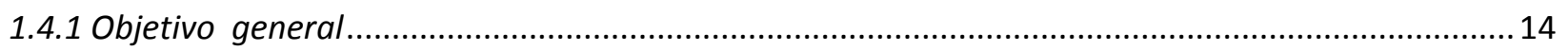

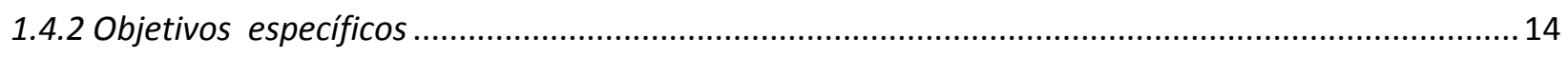

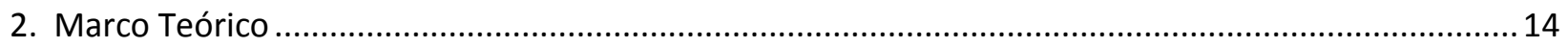

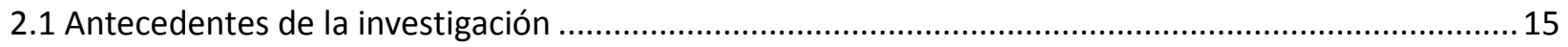

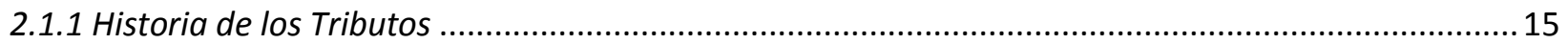

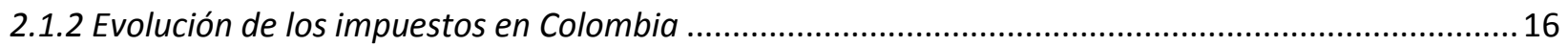

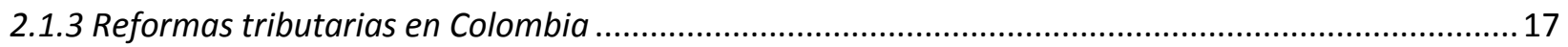

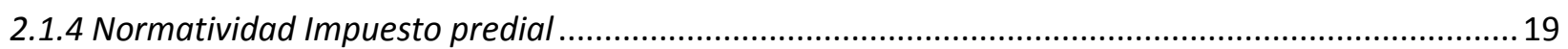

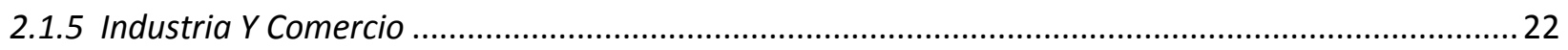

2.2.6 Antecedentes del Impuesto de Industria y Comercio en Colombia .................................................22

2.1.7 Territorialidad del Impuesto de Industria y Comercio, Avisos y Tableros, en Colombia .........23

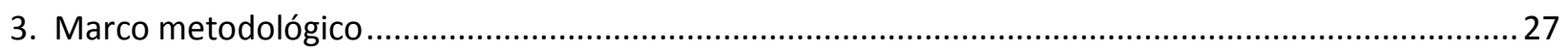

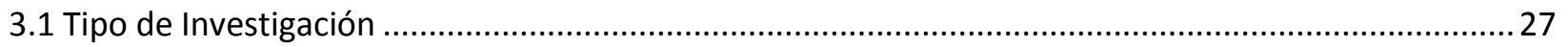

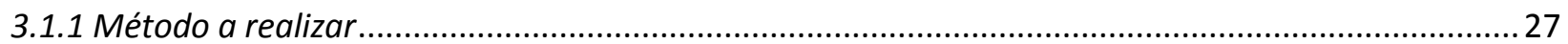

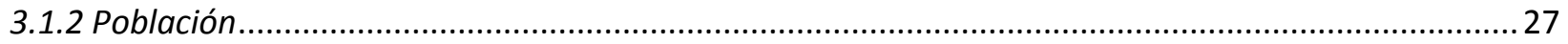

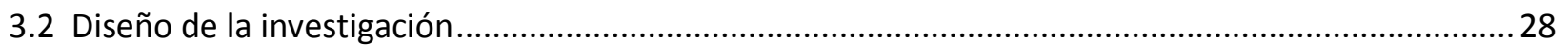

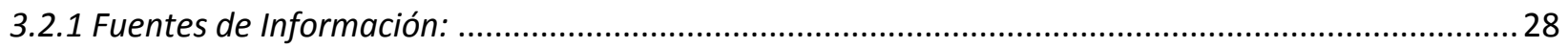

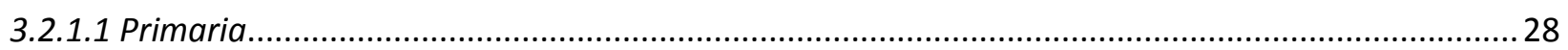

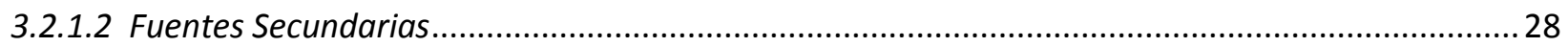

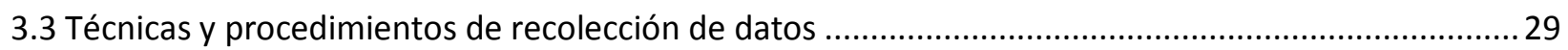

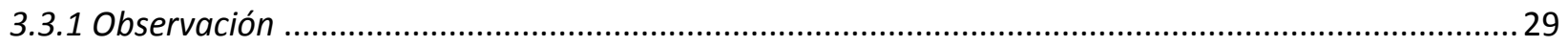

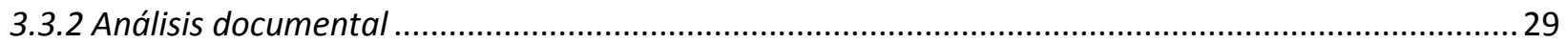

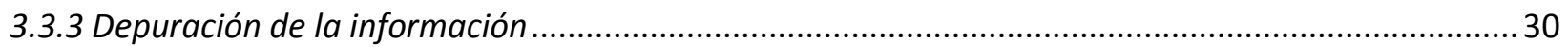

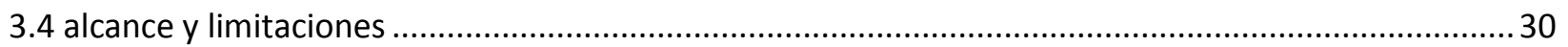

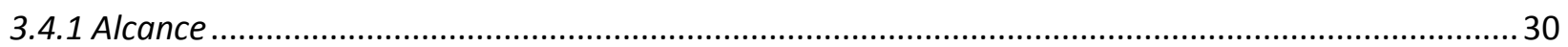




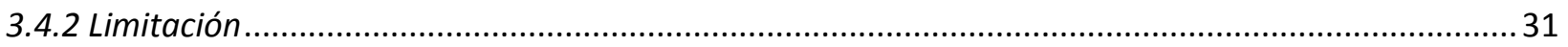

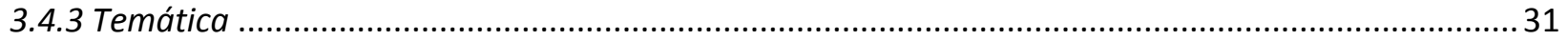

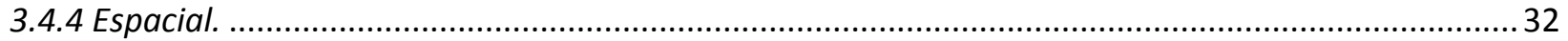

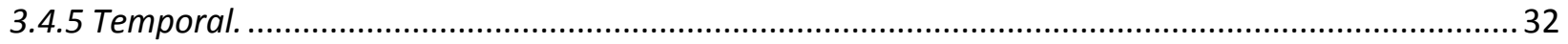

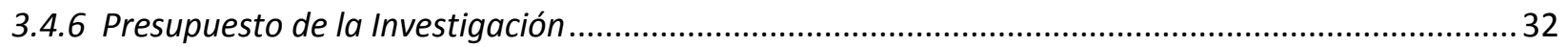

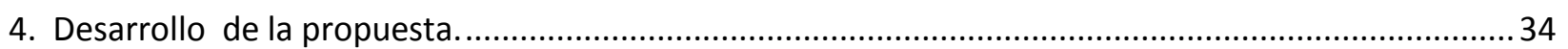

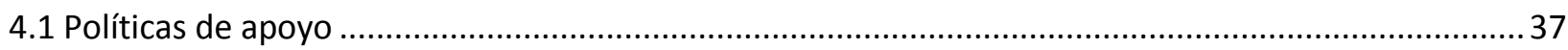

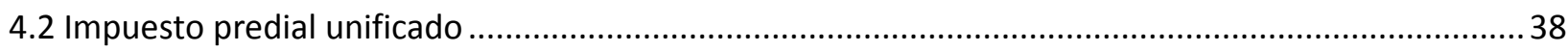

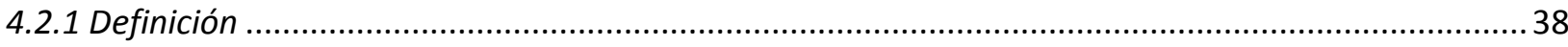

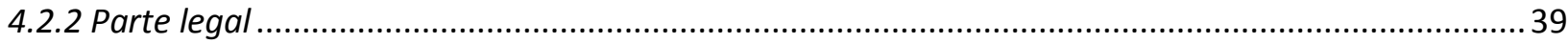

4.2.3 Criterios para definir tarifas del impuesto predial ....................................................................... 45

4.2.4 Imposición de tarifas del impuesto predial. ....................................................................................46

4.2.5 Exenciones del Impuesto Predial Unificado ....................................................................................... 51

4.2.6 Lineamientos del Impuesto Predial Unificado................................................................................. 55

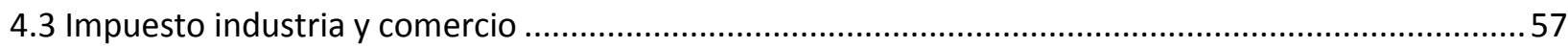

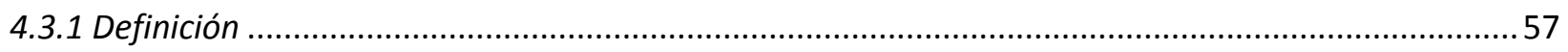

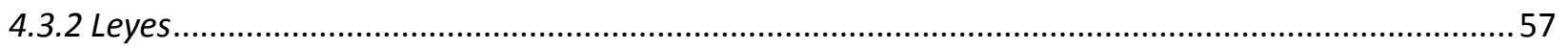

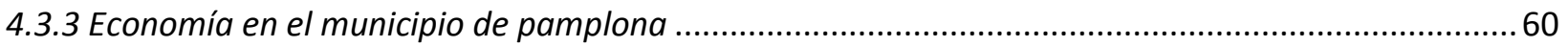

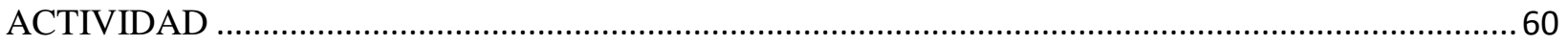

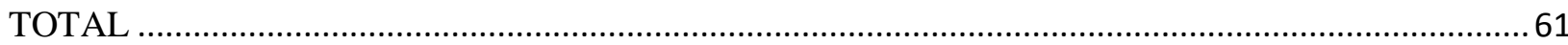

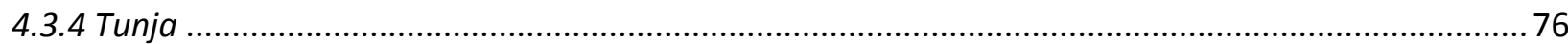

4.3.4.1 Actividades económicas de la ciudad de Tunja ................................................................................. 76

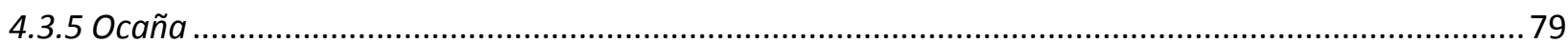

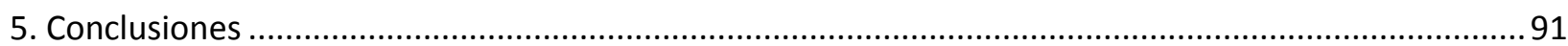

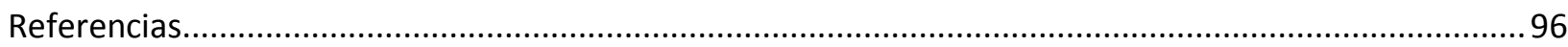

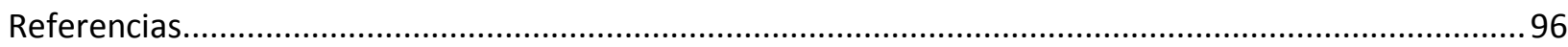

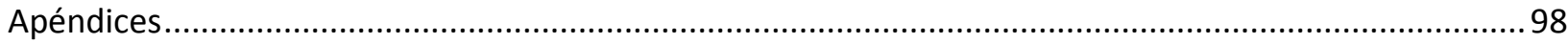

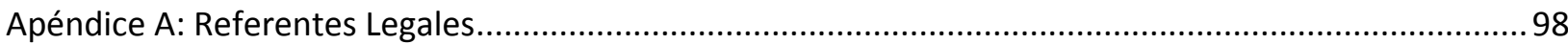

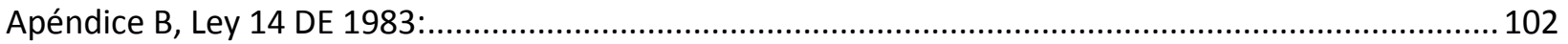




\section{Lista de Figuras}

\section{Pág.}

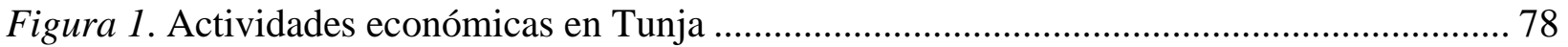

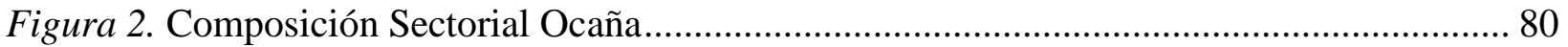

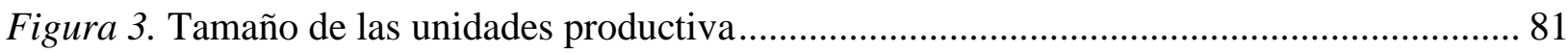




\section{Lista de Tablas}

Pág.

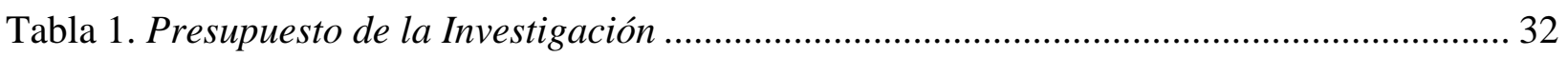

Tabla 2. Diagnóstico situacional de la Secretaria de Hacienda ................................................ 35

Tabla 3. Paralelo entre el acuerdo 027 de 2005 y normas nacionales. ..................................... 42

Tabla 4. Estructura tarifario Impuesto Predial Unificado Municipio de Pamplona .................. 47

Tabla 5. Estructura tarifario Impuesto Predial Unificado Municipio de Ocaña ........................ 48

Tabla 6. Estructura tarifario Impuesto Predial Unificado Municipio de Tunja Boyacá ............. 49

Tabla 7. Predios exentos del impuesto predial ....................................................................... 52

Tabla 8. Total de empresas inscritas por actividad económica ............................................... 60

Tabla 9. Composición de la industria de Pamplona ................................................................... 62

Tabla 10. Hoteles y residencias de pamplona .................................................................... 67

Tabla 11. Principales bienes producidos en pamplona ......................................................... 70

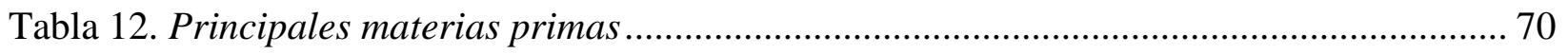

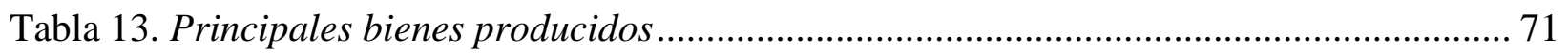

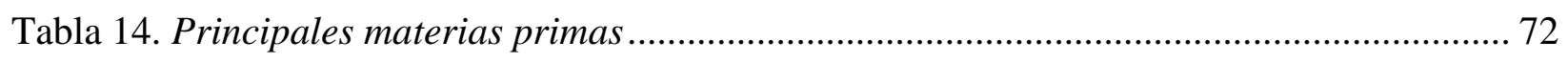

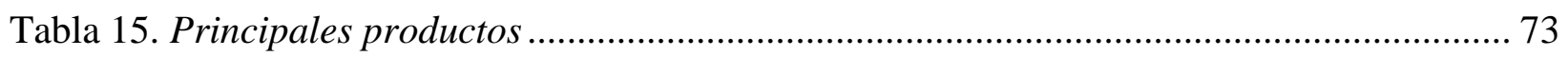

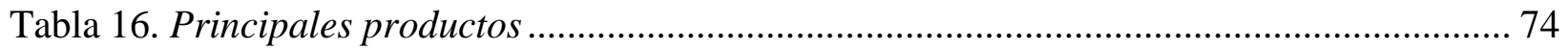

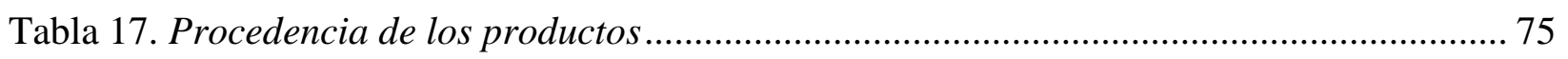

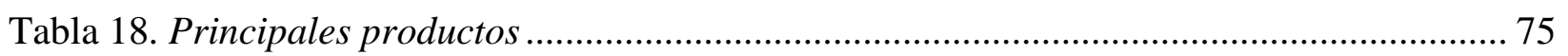

Tabla 19. Comparativo tarifas aplicadas en el impuesto de industria y comercio Pamplona,

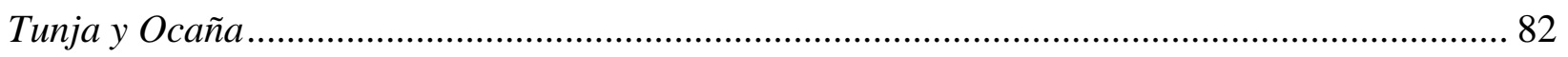

Tabla 20. Comparativos impuesto vallas, avisos y tableros Pamplona, Tunja y Ocaña.............. 88

Tabla 21. Comparativo según los ingresos presupuestados con lo recaudado .......................... 90 


\section{Resumen}

El presente trabajo de grado fue el análisis al Estatuto de Rentas del Municipio de Pamplona, Acuerdo 027 del 2005, en el cual se realizó un diagnostico a las tarifas, exenciones, y estímulos de los impuestos predial e industria y comercio, avisos y tableros comparado con tres municipios Pamplona Tunja y Ocaña.

En este diagnóstico se pudo evidenciar falencia en las tarifas del impuesto predial, e industria y comercio ya que al especificar las actividades comerciales las agrupa en otras actividades generales lo que genera que algunos contribuyentes de mayores ingresos se acojan a la tarifa general.

Se pudo evidenciar que el municipio de Tunja tiene muy bien especificada las actividades ya que las clasifica una a una y a la vez le asigna un código lo que le permite tener un mejor control para el recaudo del impuesto de industria y comercio. 


\section{Introducción}

Pamplona, es una ciudad y capital de la histórica provincia ubicado en la zona suroccidental del Departamento de Norte de Santander. Su economía está basada en el comercio gastronómico, la educación superior y el turismo, dentro del cual se destaca el religioso (especialmente durante Semana Santa).

La producción agrícola, la explotación pecuaria, bovinas, porcinas, piscicultura, cutícula y aves de corral, Actividad comercial: producción de alimentos como dulces y colaciones, producción de tejidos, la industria hotelera y turismo.

Es importante destacar, que ésta es una ciudad estudiantil, lo cual está enfocada a la industria hotelera y turismo, es probablemente la principal actividad económica actual del municipio, donde miles de estudiantes son albergados y alimentados, así también son los principales consumidores en los centros nocturnos y los innumerables cibercafés que desde hace un par de años han proliferado por la gran demanda que posee.

El grupo de investigación ha querido elaborar este proyecto ya que consideramos importante el tema de los impuestos, Pamplona es una ciudad dinámica y con mucha proyección ya que la Universidad atrae mucho estudiante foráneo y ese permite a los habitantes del Municipio buscar alternativas de empleo. 
También, es cierto que al ofrecer algún tipo de bien o servicio se está generando una responsabilidad no solo con los beneficiarios sino con el Municipio, y es la de pagar los impuestos que le permita a la Administración obtener recursos para invertirlos en las diferentes necesidades que presenta el Municipio.

La vivienda en el sector urbano, es difícil de calcular ante la usencia de datos estadísticos actualizados de los registro de los contribuyentes ya que no se han realizados actualizaciones catastrales desde el año 2003 al sector urbano, y desde 1992 al sector rural.

Es importante que, el Municipio conozca la realidad de Pamplona, a nivel económico, educación, social que le permita tener una visión más amplia de las fortalezas y debilidades que se presentan y más en materia de impuestos que es un tema difícil de abordar y pretender que todas las personas tengan una misma idea y que cumplan con sus obligaciones es difícil.

Por esta razón, presentamos nuestro proyecto de grado como contribución a mejorar y fortalecer de alguna manera la gestión y los procesos de la Secretaria de Hacienda y que esto redunde en beneficio para el Municipio, con una comparación exhaustiva de los estatutos de Renta del Municipio de Pamplona, Tunja y Ocaña, en cuanto a los impuesto Predial, Industria y Comercio, Avisos y tableros. 


\section{Análisis del estatuto único de rentas del Municipio de Pamplona en relación a las tarifas, exenciones, y estímulos de los impuestos predial e industria y comercio, avisos y tableros y comparado con tres municipio Pamplona Tunja y Ocaña.}

\subsection{Planteamiento del problema}

Los primeros hombres y mujeres que habitaron la tierra eran nómadas. Se alimentaban de las plantas que recogían, de animales que cazaban y de peces que pescaban; posteriormente aprendieron a cultivar plantas y a criar animales así se hicieron agricultores y ganaderos sedentarios, dando origen a las poblaciones, que debían protegerse y cubrir necesidades comunes.

Los sumerios, quizás el pueblo más antiguo que se conoce, pues fue el primero en tener escritura. Existió en sumeria un sistema tributario en el cual los sacerdotes eran los encargados de recaudar los tributos, por la variedad y cantidad de tributos que se daban, los sacerdotes no podían confiar en su memoria, lo que hiso necesario crear un sistema para el registro de las transacciones.

En lo referente a Colombia, el Articulo 76 de la Constitución de 1886, señalo la función del congreso de hacer las leyes y conferir atribuciones especiales a las asambleas departamentales, el artículo 190 de la misma constitución ordena que las asambleas departamentales para cubrir los gastos de administración pudieran establecer contribuciones. 
Dentro de los límites establecidos por las leyes, y el artículo 199 de misma constitución de 1886, atribuyo a los concejos municipales votar de conformidad con las ordenanzas expedidas por las asambleas, las contribuciones y gastos locales.

La ley 4 de 1913 en su artículo 169 (Ley 4, 1913 ) le concede a los concejos Municipales la atribución de imponer contribuciones para el servicio municipal dentro de los limites señalados por la ley y las ordenanzas, la ley 97 de 1913 otorgo libertada a algunos municipios para crear sus propios impuestos sin que mediera autorización de las asambleas departamental, en esta norma se da un primer asomo del impuesto territorial de industria y comercio creándose el impuesto de avisos y tableros el cual fue, extendiéndose y ajustándose de forma generalizada a todos los territorios municipales por la Ley 84 de 1915.

La Ley 14 de 1983, fue la norma marco que fortaleció los fiscos de las entidades territoriales, enmarcando el impuesto de industria y comercio, avisos y tableros y otros impuestos complementario a ese tributo. Posteriormente se expidieron la Ley 55 de 1985, Ley 43 de 1987, Ley 49 de 1990 y Decreto 1333 de 1986, normas que modificaron y reglamentaron la ley marco de los impuestos territoriales, entre otras y se expidió el Decreto 624 de 1989 "Estatuto Tributario Nacional" que de modelo para que los municipios implementaran sus regímenes sancionatorios y de procedimiento para el cumplimiento de las obligaciones tributarias en cada uno de los entes territoriales.

En Colombia, los impuestos han sido un problema de hace tiempo, donde la corrupción y la política han hecho desaparecer los beneficios reales de los impuestos en su reciprocidad a los 
contribuyentes, y más crítica la situación hacia los municipios que sufren de una centralización real práctica contrario a lo establecido en la Ley, y para ello requieren recursos Humanos, materiales, financieros, y de un marco jurídico apropiado para el recaudo de sus ingresos.

La Administración, debe manejar un sistema de incentivos y desincentivos en el comportamiento tributario. El mejor de los incentivos es la existencia de un sistema fiscal que permita lograr el crecimiento económico y social a través del gasto.

La obligación de pagar impuestos, nunca ha sido responsabilidad acogida con entusiasmo en ningún país del mundo cabe aclarar que los ingresos tributarios en las Entidades Territoriales constituyen su principal fuente de recursos propios pero la experiencia ha demostrado que las administraciones locales se limitan a recaudar sus tributos que voluntariamente pagan los contribuyentes, sin implementar creatividad, tecnología y recursos a la gestión tributaria con miras a lograr recaudos suficientes para el financiamiento del gasto público local, el cual depende de los recursos de la nación y de los recursos del crédito.

La evasión de impuestos y el tratamiento inequitativo al establecerlos, han contribuido significativamente a que la situación económica de los Municipios y Departamentos del país sean de constante déficit, sumado a las múltiples funciones que se les asignan, para que sean asumidas con sus propios recursos, sin que se brinde por parte del Gobierno Nacional a los Municipios, herramientas de orden legal que les garantice el correcto recaudo y la aplicación adecuada de los procedimientos procedentes en caso del incumplimiento por parte de los sujetos pasivos. 


\subsection{Formulación del problema.}

¿Cómo hacer eficiente el Código Único de Rentas del Municipio de Pamplona en relación a las tarifas, exenciones, y estímulos de los impuestos predial e industria y comercio en comparación con tres Municipio Pamplona Tunja y Ocaña?

\subsection{Justificación del problema.}

El trabajo de investigación a realizar cobra importancia desde el mismo momento de conocerse la fecha de aprobación del (Acuerdo 027, 2005), su desactualización y el no adecuado establecimiento de los tributos es una verdad que vienen manifestando los funcionarios de la secretaria de hacienda del Municipal de Pamplona Norte de Santander.

El trabajo conllevara a plantear modificaciones en el Título II del Libro I del código de rentas del Municipio de Pamplona en sus artículos 29 al 294, lo que posiblemente evitara la pérdida de recursos que por orden legal le pertenecen al ente territorial, fortalecimiento de su capacidad de inversión y de funcionamiento, contrario sería evitar que se sigan abusando del contribuyente al estarse cobrando en exceso de lo contemplado orden legal.

Este trabajo de investigación permitirá que el grupo de trabajo que lo realiza reafirme los conocimientos adquiridos en materia de impuestos territoriales los cuales fueron vistos en la especialización de Gerencia Tributaria XIX cohorte. 


\subsection{Objetivos}

\subsubsection{Objetivo general}

Analizar el Código Único de Rentas Municipal Vigente de Pamplona en relación a las tarifas, exenciones, y estímulos de los impuestos Predial e Industria y Comercio, Avisos y tableros, comparada con tres Municipio Pamplona Tunja y Ocaña

\subsubsection{Objetivos específicos}

- Realizar un diagnóstico situacional de las actividades y su relación con el entorno con tal de identificar sus fortalezas, debilidades, oportunidades y amenazas en el Municipio de Pamplona.

- Estudiar si las Bases tarifarias, exenciones y estímulos del Estatuto de Rentas del Municipio de Pamplona comparada con Tunja y Ocaña se encuentra bajo la normatividad legal vigente.

- Realizar un comparativo de las tarifas, exenciones y estímulos del impuesto predial e industria y comercio, avisos y tableros frente a los Municipio de Ocaña y Tunja para conocer los aspectos relacionados entre sí y sus principales diferencias.

\section{Marco Teórico}




\subsection{Antecedentes de la investigación}

\subsubsection{Historia de los Tributos}

La historia de los tributos, se remota a los albores de la civilización3. Encontrar que los impuestos, tributos y contribuciones que los ciudadanos pagamos al estado y que además influyen de gran manera en la situación económica y social no son una costumbre reciente, desde tiempo antiguos se conocen reseñas sobre estas costumbres cuya finalidad es dar recursos a los países para su inversión y funcionamiento.

Es claro que, la raíz de los tributos nace desde la época primitiva del hombre donde se conoce que estos entregaban ofrendas a sus dioses a cambio de algunos beneficios, costumbre que todavía existen en algunas sociedades4. Otro aspecto que permanece es el tributo como medio de sustento para la guerra, en este caso basta ver nuestra situación actual puesto que cada que necesitan más recursos plantean nuevas reformas tributarias ampliando el universo de contribuyentes y gravando nuevos conceptos. Otros de los principios que se aprecian es que desde la civilización griega se maneja la progresividad en el pago de los impuestos, aunque es triste ver que se desvirtúo su ausencia ya que actualmente, se puede apreciar que la clase pobre paga igual o más que aquellos que se encuentran en los altos estatus y es difícil que este principio recobre su original significado a raíz de otro concepto que se conserva desde antiguas civilizaciones "el manejo de la política fiscal" que según estudios actuales no ha funcionado o no ha cumplido su cometido. 
En tiempos antiguos además de recaudar los tributos, también los controlaron, administraron y clasificaron. Para su control nace la figura de inspector de finanzas, actualmente conocido como contralor y para su registro y comprobación estaría y se mantiene la contabilidad. Cabe destacar que no en las organizaciones estatales de la época antigua existió el descontento, la mala distribución de los recaudos realizados por los impuestos. En las culturas indígenas como la Inca, Azteca y Chibcha, se pagaba los impuestos de manera justa, ya que tenían un sistema tributario bien organizado y bien controlado, inclusive tenían estatuto sancionatorio para quienes fuera infractores de los tributos.

\subsubsection{Evolución de los impuestos en Colombia}

Para Colombia en el siglo XIX, es importante destacar la instauración del actual impuesto sobre la renta. Aunque es claro que no era fácil entrar a cobrar impuestos debido a que las personas consideraban que si se habían independizado era para no tener que pagar altos tributos.

A pesar de la situación anterior, a medida que avanza el proceso de conformación de la república, el sistema tributario se va acomodando a las nuevas circunstancias siempre bajo la influencia obviamente de la Nación Europea líder en esta materia.

Ya en la época de la llamada confederación granadina se hicieron varias modificaciones que eran sostenibles de buenos resultados en lo económico, pero las constantes guerras civiles que conocemos de nuestra historia, dieron el traste como buena parte de los objetivos que se crearon. Además el país no está preparado para administrar las reformas debido a la inestabilidad social y 
la falta de gobiernos fuetes y buenos administradores, situaciones que en conjunto, impidieron que el sistema tributario funcionara y prosperara.

En el siglo XX para nuestro país, es lógico que se inicie con las dificultades heredadas del anterior: en guerra civil sin recursos y emisiones de monedas que deterioraron su poder adquisitivo. (Restrepo, 2006)

\subsubsection{Reformas tributarias en Colombia}

Más adelante, en los diferentes gobiernos, los que más se destacaron en cuanto a aspectos tributarios: Es el gobierno de Belisario Betancur se amplía el cobro del IVA al sector económico terciario, gobierno de Virgilio Barco destacado por el gran nivel de desempleo y la alta tributación emitió el estatuto tributario y dirigió su reforma tributaria a dirigir las finanzas públicas. (Birg , Poterra, \& Slemron, 2006)

En el gobierno de Cesar Gaviria Trujillo, efectúo la tal polemizada apertura económica cuando el país no se encontraba preparado para para asumir sus consecuencias, convocó a la asamblea constituyente y dentro de su legislación tributaria destacó la reglamentación en la ley 43 de 1990 de la profesión del contador público y en 1991 se promulga nuestra actual constitución. (Birg , Poterra, \& Slemron, 2006) 
El gobierno de Ernesto Samper Pizano recibe el país con apertura económica y con su programa de salto social, prometió entre otras cosa no aumentar las tasas impositivas, sino racionalizar el recaudo.

El gobierno de pastrana instituyo el 2x1000 a través de una emergencia económica hoy en día gravamen a los Movimientos Financieros 4x1000.

El gobierno del presidente Álvaro Uribe Vélez que recibe al país con grandes problemas sociales, altas tasas de desempleo. Se realizaron varias reformas tributarias entre ellas la ley 788/2002 y la ley 863 del 2003, seguidamente la reforma pensional, en el año 2005 la ley 1004 de 2005 consagró una tarifa especial para las sociedades que eran calificadas por el Gobierno como zona franca especial. Estas grandes sociedades tienen el 15\% como tarifa de renta, frente al resto de sociedades que tributan a la tarifa general del 33\%. (Birg, Poterra, \& Slemron, 2006)

En el actual gobierno del presidente Juan Manuel Santos se crea la ley 1370 de 2009 respecto al impuesto al patrimonio creado en la emergencia invernal, lo que llevó a declarar la emergencia económica, social y ecológica (D. leg. 4580/2010), 31 en virtud de la cual el ejecutivo asumió funciones legislativas y creo un nuevo impuesto al patrimonio (D. Leg. 4825/2010), para obtener los recursos para la atención humanitaria, la rehabilitación y construcción de zonas afectadas, con dos componentes. (Santos, 2006)

El nuevo impuesto al patrimonio para las emergencias invernales, señala que el gravamen debe "pagarse en ocho cuotas iguales, durante el año 2011, 2012, 2013 y 2014. También se crea 
la ley 1430 de 2010 de control y competitividad adoptó medidas en materia de impuesto de renta, de GMF, del patrimonio, del IVA, de procedimientos, de Impuestos territoriales y otros asuntos varios no propiamente tributarios.

Se crea una nueve reforma tributaria la Ley 1739 que tiene como propósito la consecución de recursos a través de la creación de nuevas rentas y la modificación de las existentes para reducir el déficit del Presupuesto.

\subsubsection{Normatividad Impuesto predial}

Aspectos normativos del impuesto predial El impuesto predial es un tributo municipal que grava la propiedad raíz con base en los avalúos catastrales establecidos por el Instituto Geográfico Agustín Codazzi (IGAC), y por las oficinas de catastro y del departamento de Norte de Santander.

Las normas iniciales sobre el impuesto predial fueron expedidas durante los primeros años del siglo pasado. Con la Ley 34 de 1920 se definió una tarifa máxima del 2 por mil, que luego se incrementó en dos puntos durante la década del cuarenta con el fin de financiar el Fondo de Fomento Municipal y la Policía Rural. Desde la década del cincuenta y hasta comienzos de los ochenta, la legislación no introdujo mayores modificaciones al régimen del impuesto, salvo algunos ajustes tarifarios.

A comienzos de los ochenta, La Misión de Finanzas Intergubernamentales, destacó algunos problemas asociados al impuesto predial, como su inelasticidad frente al PIB, las deficiencias en la administración de los cobros, la desactualización de los avalúos y el gran número de exenciones, 
que cobijaban en promedio hasta el 10\% de los predios. De acuerdo con el Informe de la Misión, en 1980 las tasas efectivas de tributación fluctuaban entre 2 y 4 por mil para las capitales de departamento frente a una tarifa nominal legal de 8 por mil. Para el resto de municipios, la tarifa promedio efectiva se estimó en 2.6 por mil frente al 4 por mil establecido en la Ley.

Por todo lo anterior, la Misión encontró que Colombia era uno de los países latinoamericanos con el rendimiento más bajo de tributación a la propiedad (Misión de Finanzas Intergubernamentales, 1981). A partir de las recomendaciones de la Misión y con el objeto de elevar el nivel de los recaudos municipales, se expidió la Ley 14 de 1983, la cual introdujo modificaciones de fondo en el manejo de los impuestos regionales y locales. En el caso del impuesto predial la Ley realizó las siguientes modificaciones: i) estableció el reajuste de los avalúos catastrales, ii) facultó a los Concejos Municipales para fijar las tarifas del impuesto dentro de un rango entre el 4 y 12 por mil, y iii) definió algunas sobretasas con destinación específica. Posteriormente, la Ley 75 de 1986 realizó algunos ajustes a los criterios y periodos de actualización de los avalúos catastrales definidos en la Ley 14. 14 Ley 44 de 1990 estableció el impuesto predial unificado, mediante la fusión del impuesto predial, el de parques y arborización, el de estratificación socioeconómica y la sobretasa al levantamiento catastral. Así mismo, definió que la base del impuesto sería el avalúo catastral o el autoevalúo, una vez establecido el mecanismo de la declaración anual del Impuesto. También se modificó el rango de tarifas para situarlo entre el 1 y el 16 por mil, dejando la posibilidad de gravar con una tarifa de hasta el 33 por mil los lotes urbanizables no urbanizados. Para la definición de estas tarifas los Concejos municipales, siguiendo principios de progresividad, deberían tener en cuenta los siguientes criterios: i) el estrato 
socioeconómico; ii) el uso del suelo en el sector urbano; y iii) la antigüedad de la formación o actualización del catastro.

De otro lado, la Ley señaló que al menos el $10 \%$ del recaudo del impuesto se destinaría a financiar un fondo de habilitación de vivienda de estrato bajo y a la adquisición de terrenos destinados a la construcción de vivienda de interés social. Con relación al valor de los avalúos catastrales, la Ley ordenó que el gobierno nacional, previo concepto del CONPES, debería fijar incrementos anuales que no fuesen ni inferiores al 70\% ni superior al 100\% del IPC observado. Los criterios para efectuar los reajustes anuales de los avalúos catastrales fueron revisados por la Ley 242 de 1995, que introdujo el criterio de meta de inflación total, y la Ley 388 de 1997, que discriminó los criterios para los incrementos con base en el tipo de predio.

Para el caso de Bogotá, el Decreto-Ley 1421 de 1993 señaló que a partir del año gravable de 1994, la base del impuesto sería el valor que mediante autoevalúo estableciera el contribuyente, el cual no podría ser inferior al avalúo catastral del año inmediatamente anterior. La aplicación de estas normas, se reflejó en los incrementos de los avalúos catastrales. Los Concejos Municipales, a lo largo del tiempo, han venido aprobando una serie de tratamientos preferenciales que incluyen exclusiones, exenciones, y reducciones especiales en la tarifa y en el valor del impuesto predial.

La ley 1430 del 2010, amplia el concepto de sujeción pasiva al impuesto predial para cuando se trate de predios vinculados o constitutivos de un patrimonio autónomo, imponiendo la obligación sobre los respectivos fideicomitentes o beneficiarios del respectivo patrimonio y sobre los tenedores de inmuebles públicos a título de concesión. 
Ley 1450 modifica el artículo 4 de la ley 44/90 aumentando el rango mínimo de la tarifa del predial, pasando del uno por mil al cinco por mil. Incluye dos nuevos para la determinación de la tarifa: a) el rango de área y b) el avalúo catastral.

A la propiedad inmueble urbana con destino económico habitacional, o rural con destino económico agropecuario estratos 1, 2 y 3 y cuyo precio sea inferior a 135 SMLMV, le ordena aplicar tarifas entre el uno por mil y el dieciséis por mil.

\subsubsection{Industria Y Comercio}

\subsubsection{Antecedentes del Impuesto de Industria y Comercio en Colombia}

El Impuesto de Industria y Comercio, Avisos y tableros, tal como hoy en día se conoce a este tributo en Colombia, uno de los gravámenes más importantes del sistema tributario nacional, ha tenido una evolución histórica interesante, más sin embargo, no ha sido muy analizada como si ha ocurrido con otros impuestos. Este impuesto tiene su origen más remoto en la Edad Media, quienes quisieran realizar alguna actividad comercial, industrial o un oficio de terminado, debían pagar al señor Feudal o soberano de turno. A los vasallos se les otorgaba un permiso o carta patente; sin embargo se mantenía una exención para los nobles, los Hidalgos y para los miembros de la Iglesia. La cuantía del tributo se establecía con base en tres factores: (i) La intuición por parte del recaudador, (ii) Su autoridad, y (iii) la soberanía del príncipe. (Garcia peña, 2008), Impuesto de Industria y Comercio, Avisos y tableros en Colombia. 
El Impuesto de Industria y Comercio en Colombia nace en 1826, cuando se estableció una contribución industrial obligatoria mediante la cual se obligaba a todas las personas que desarrollaban actividades industriales, comerciales, artes y oficios, a obtener una patente de Funcionamiento. Este régimen perdura sin variaciones importantes hasta 1913, cuando se dictó la Ley 97 para Bogotá.

Este impuesto se ha constituido como uno de los principales tributos de los entes territoriales, municipales y su expansión ha hecho que surjan todo tipo de interrogantes entre los conocedores del tema.

El Impuesto de Industria y Comercio ha sido objeto de un largo proceso de evolución normativa, en el que las autoridades municipales fueran estableciendo algunos gravámenes sobre de terminadas actividades, luego se fueron estableciendo regulaciones complementarias y paulatinamente se realizaron precisiones hasta llegar a lo que es hoy en día, un impuesto que grava los ingresos que perciben las personas naturales y jurídicas y sociedades de hecho producto de la realización dentro de terminada jurisdicción distrital o municipal de actividades industriales, comerciales y de servicios y complementariamente por la colocación de avisos en el espacio público.

2.1.7 Territorialidad del Impuesto de Industria y Comercio, Avisos y Tableros, en Colombia 
El principio de territorialidad en el Impuesto de industria y comercio, supone que un de terminado municipio, sólo puede cobrar el respectivo impuesto sobre los ingresos obtenidos en su jurisdicción, lo que lleva a que el contribuyente para determinar la base gravable, deba restar del total los ingresos, los ingresos obtenidos o generados en otros municipios.

Se considera que el sujeto pasivo o contribuyentes ha obtenido ingresos en un municipio cuando ha desarrollado actividades comerciales, industriales o de servicios en su jurisdicción, utilizando o no un establecimiento comercial. El sólo hecho de llevar a cabo la operación gravada en predios del municipio ya lo convierte en responsable del impuesto. La ley 14 de 1983 ya no exige que la realización del ingreso se haga mediante Establecimientos de comercio, Sucursales comerciales o Agencias comerciales, es suficiente con que se haga uso de las instalaciones e infraestructura de un municipio para generar el ingreso, para que se deba tributar en el respectivo municipio.

En principio no debe existir dificultad alguna para determinar cuándo un ingreso es generado en uno o en otro municipio, pero hay casos en que el hecho generador sucede en varios municipios al tiempo, o se requiere que en cada municipio se desarrolle un proceso diferente, por lo que en estos casos resulta complicado de terminar en cuál de todos se deben pagar los Impuestos.[gerencie.com, 2010]

En la exposición de motivos de la mencionada ley 14, se indicó que el municipio llamado a percibir el tributo, era aquel que pusiera a disposición del prestador de la actividad, la infraestructura necesaria para desarrollarla. Se indicó que la voluntad del legislador era gravar las 
actividades realizadas por las personas que se beneficiaban de los recursos, la infraestructura y la de manda del municipio, lo cual conlleva es a mirar la relación que existe entre el ejecutor de la actividad y el ente territorial y no las condiciones en que la actividad se desarrolla. Esto es, porque el impuesto de industria y comercio es un gravamen real y no personal. Al ser un gravamen real, se debe observar en dónde se realiza la actividad y no, cuales son las condiciones y circunstancias en que se desarrolla la materia imponible. Es por eso que, el factor para determinar el sujeto activo del tributo, no es dónde se firma el contrato ni para dónde se envía la mercancía objeto de venta. Es por esto también que el sujeto pasivo del gravamen será el municipio desde dónde se presta el servicio y no el municipio destino del servicio.

En el campo jurisprudencial se ha venido desarrollando criterios orientadores que nos determinan quién es el sujeto activo del tributo.

En primer lugar se señaló que el impuesto de industria y comercio, según las normas vigentes, es un solo impuesto, de manera que, una misma actividad no puede gravarse como industrial y comercial. Es por esto que al industrial se le grava en el lugar donde está ubicada la sede fabril independientemente del destino de las mercancías y de la modalidad de comercialización. También nos lleva a decir, que para el caso en que el industrial decido ubicar los de nominados puntos de fábrica en el mismo territorio donde está ubicada la sede fabril o, instalar establecimientos de comercio en sitios distintos al lugar de ubicación de la sede fabril, continua siendo industrial y por consiguiente, tributará con tarifa de industrial inclusive, en el municipio donde tenga el establecimiento de comercio. 
El industrial produce para vender. Tiene vocación de vendedor y por consiguiente, fuere donde fuere, tributa con tarifa de industrial.

En tercer lugar, la materia imponible recae sobre la realización de la actividad y no por tener un establecimiento de comercio. Recordemos que el establecimiento de comercio no es el sitio donde se realiza la actividad. El establecimiento de comercio es algo inanimado, carente de personería jurídica y según la ley comercial, es el conjunto de bienes que tiene el comerciante para realizar la actividad. Que los bienes pueden estar en un sitio, es válido. Pero, teniéndose en cuenta que el establecimiento son los bienes, no el sitio. Entonces y continuando con el desarrollo del concepto, el sujeto pasivo del tributo será el municipio donde se realice la actividad, no el municipio donde se tenga el establecimiento de comercio.

En cuarto lugar, debemos decir que al ser el sujeto pasivo la persona que realiza la actividad, es decir, donde realizo la materia imponible, la base gravable, es decir, lo que gano en ese territorio, será el monto sobre el cual se aplica la tarifa, siendo imposible entonces, que un mismo ingreso quede gravado en varias oportunidades y por distintos sujetos pasivos.

En conclusión, la materia imponible es clara. Lo que no hay es claridad por parte de quienes la aplican. 2. Leyes y Normas que Regulan los Impuestos Municipales 


\title{
3. Marco metodológico
}

\subsection{Tipo de Investigación}

\author{
Analítica
}

\subsubsection{Método a realizar}

Analítico-deductivo los investigadores analizan el estatuto único de rentas del municipio de pamplona en relación a las tarifas, exenciones, y estímulos de los impuestos predial e industria y comercio, avisos y tableros y comparado con tres municipio pamplona Tunja y Ocaña

\subsubsection{Población}

Estatuto de rentas del municipio de Pamplona, Ocaña y Tunja con relación a las tarifas, exenciones, y estímulos de los impuestos predial e industria y comercio, avisos y tableros 


\subsection{Diseño de la investigación}

La metodología a seguir en la investigación incluye la consecución y el análisis de datos primarios y secundarios para poder conocer aspectos significativos desde el punto de vista cualitativo y cuantitativo.

\subsubsection{Fuentes de Información:}

\subsubsection{Primaria}

Leyes, Conceptos del Ministerio de Hacienda y Crédito, Resoluciones del Instituto Geográfico Agustín Codazzi, leyes del Ministerio de Transporte Acuerdos del Concejo de Pamplona, Tunja y Ocaña.

\subsubsection{Fuentes Secundarias}

- $\quad$ Acuerdo 027 del 2005.

- Libros de Impuestos Territoriales.

- Revistas Tributarias.

- Normas y Reglamentaciones.

- Informes de Gestión Secretaria de Hacienda Municipal de Pamplona.

- Investigaciones Económicas grupo UNIR.

- Artículos Internet. 


\subsection{Técnicas y procedimientos de recolección de datos}

En virtud de lo expresado por Sabino (1994), un instrumento de recolección es en principio cualquier recurso metodológico del cual puede valerse el investigador para acercarse a los fenómenos estudiados y extraer de ellos la información. En ese orden de ideas, para la variable de estudio el recurso utilizado para recabar información fue el cuestionario, además de ella se utilizaron las siguientes técnicas.

\subsubsection{Observación}

Mediante esta técnica se facilita la obtención de información tanto cualitativa como cuantitativa, este procedimiento implica la selección, la vigilancia y el registro sistemático del comportamiento, de la conducta y de las características del sujeto en observación.

\subsubsection{Análisis documental}

Esta parte está basada en el estudio y el análisis efectuado a las fuentes de información interna como externas aportadas con el objeto primordial de conocer los factores que intervienen en el proceso productivo. 


\subsubsection{Depuración de la información}

Se depurará la información dependiendo la relevancia que muestre para el objeto de esta investigación; teniendo en cuenta factores cómo:

- Pertinencia

- Coherencia

- Relevancia

Una vez seleccionada y clasificada la información, se procederá a su análisis a fin de obtener el resultado esperado con este proyecto.

\section{4 alcance y limitaciones}

\subsubsection{Alcance}

Geográficamente el estudio incluye al Municipio de Pamplona en especial el centro urbano por considerarse representativo en el Departamento Norte de Santander por la cantidad de estudiantes que llegan de diferentes parte del mundo a realizar sus estudio y que genera de manera directa un incremento en la economía Municipal ya que la gran mayoría las familias se dedican a prestar el servicio de hospedaje y alimentación contribuyendo de esta manera al desempleo. En relación con el alcance, los resultados del estudio benefician de manera general al Municipio de Pamplona ya que al conocer las diferencias en cuanto a tarifas, estímulos y exenciones de los 
impuesto Municipales presentes en el acuerdo 025 del 10 de diciembre del 2005, se pueda por parta de la administración y Concejo Municipal tomar los correctivos del caso

\subsubsection{Limitación}

La falta de información o estudios preliminares a los Estatutos de Rentas Municipales, como también la falta de estudios de las actividades económicas más representativas y productivas del Municipio de Pamplona y su aporte a la economía del mismo.

\subsubsection{Temática}

Los retos que impone la sociedad del conocimiento requieren que los futuros profesionales tengan una formación integral, en la cual se debe permitir a los estudiantes que en el desarrollo de sus prácticas profesionales tengan acceso a experiencias reales, constituyéndose como una generadora de conocimientos y la herramienta principal para nuestra formación profesional. Poniendo empeño en el conocimiento de nuestra realidad laboral y ser capaces de promover el cambio en el Municipio de Pamplona hacen que los conocimientos adquiridos en el aula de clase se conviertan en la mejor herramienta para sacar adelante una propuesta donde podamos ocasionar dentro de la organización una trasformación positiva en el ámbito de impuestos vistos en la Especialización en gerencia Tributaria modulo Impuestos Territoriales y que a la vez nos demostremos que tenemos las capacidades para enfrentarnos a la vida laboral con bases sólidas y competitivas, para realizar un análisis del estatuto único de rentas del municipio de pamplona en el marco de las normas nacionales vigentes sobre impuestos territoriales, (capítulos I impuesto 
predial, II industria y comercio, III avisos y tableros y IV impuesto circulación y transito), en el Municipio de Pamplona.

\subsubsection{Espacial.}

El análisis de las debilidades que tienen el Estatuto de Rentas frente a la realidad economía del Municipio se realizará en la Alcaldía del Municipio de Pamplona, Secretaria de Hacienda Municipal.

\subsubsection{Temporal.}

La investigación se inició el segundo semestre del 2015 y se entregara a finales de Octubre del 2015.

\subsubsection{Presupuesto de la Investigación}

Tabla 1. Presupuesto de la Investigación

\begin{tabular}{lccc}
\hline \multicolumn{1}{c}{ CONCEPTO } & $\begin{array}{c}\text { No. De } \\
\text { personas }\end{array}$ & $\begin{array}{c}\text { VALOR } \\
\text { TOTAL }\end{array}$ & $\begin{array}{c}\text { TOTAL } \\
\text { GENERAL }\end{array}$ \\
\hline Investigadores & 4 & $\$ 400.000$ & $\mathbf{\$ 1 . 6 0 0 . 0 0 0}$ \\
\hline \multicolumn{1}{c}{ GASTOS GENERALES } & CANTIDAD & $\begin{array}{c}\text { VALOR } \\
\text { UNITARIO }\end{array}$ & TOTALES \\
\hline Papelería & & & $\mathbf{2 1 . 0 0 0 , 0 0}$ \\
\hline Resma de papel carta & 2 & $21.000,00$ & \\
\hline $\begin{array}{l}\text { Gastos Procesamiento de la } \\
\text { información }\end{array}$ & & & $\mathbf{2 2 0 . 0 0 0 , 0 0}$ \\
\hline Tinta Impresora negro & 1 & $\$ 85.000,00$ & \\
\hline
\end{tabular}




\begin{tabular}{lccc}
\hline \multicolumn{1}{c}{ CONCEPTO } & $\begin{array}{c}\text { No. De } \\
\text { personas }\end{array}$ & $\begin{array}{c}\text { VALOR } \\
\text { TOTAL }\end{array}$ & $\begin{array}{c}\text { TOTAL } \\
\text { GENERAL }\end{array}$ \\
\hline Tinta impresora color & 1 & $\$ 90.000,00$ & \\
\hline Impresiones & $\$ 45.000,00$ & \\
\hline Gastos Varios & & $\mathbf{2 9 0 . 0 0 0 , 0 0}$ \\
\hline Fotocopias & $\$ 50.000,00$ & \\
\hline Consultas en Internet & $\$ 60.000,00$ & \\
\hline Llamadas Celular & $\$ 20.000,00$ & \\
\hline Otros Gastos & $\$ 120.000,00$ & \\
\hline Encuadernación Informe Final & $\$ 40.000,00$ & \\
\hline TOTAL NETO DE GASTOS & & $\mathbf{2 . 1 3 1 . 0 0 0 , 0 0}$ \\
\hline
\end{tabular}

Fuente: elaboración Propia 


\section{Desarrollo de la propuesta.}

El Municipio de Pamplona ha logrado consolidarse en el ámbito Nacional y Departamental con un potencial de servicios educativos, comerciales y turísticos, que unidos a su desarrollo agropecuario lo han convertido en el eje de la provincia sur occidental del departamento Norte de Santander.

Se cuenta con vías que hacen fácil el acceso y el recorrido al casco urbano del municipio y a la zona rural, ya que su perímetro es atravesado por vías de carácter nacional y departamental como lo Troncal del Norte o Vía Panamericana y la vía que conduce de la capital del Departamento a la ciudad de Bucaramanga.

Así mismo su patrimonio histórico cultural le ha permitido mantener una infraestructura arquitectónica que reconocida por autoridades del orden nacional ha captado recursos para preservar monumentos históricos que hoy albergan varios museos y son centros de profesión religiosa.

La ciudad es reconocida nacional e internacionalmente como " CIUDAD EDUCADORA " logrando posicionar durante los últimos años a la Universidad de Pamplona como uno de los principales centros de educación superior del Nororiente colombiano con numerosos CREAD a nivel nacional y con numerosos convenios internacionales. 
Diagnóstico situacional de la Secretaria de Hacienda, las actividades y su relación con el entorno con el fin de identificar sus fortalezas, debilidades, oportunidades y amenazas.

Tabla 2. Diagnóstico situacional de la Secretaria de Hacienda

\begin{tabular}{|c|c|}
\hline $\begin{array}{l}\qquad \text { FORTALEZAS } \\
\text { 1. Descuento especial por pronto pago } \\
\text { 2. Ubicación de la Oficina de Impuesto } \\
\text { 3. Autonomia en el inversión de los recursos obtenidos del impuesto }\end{array}$ & $\begin{array}{l}\text { DEBILIDADES } \\
\text { 1. Actualización de la información catastratl } \\
\text { 2. Programa contable } \\
\text { 3. Capacitación al personal } \\
\text { 4. Inexactitud de la Información } \\
\text { 5. Carencia Manuel de Procedimientos } \\
\text { 6. Orientación a la comunidad } \\
\text { 7. Carencia sistema de fiscalización } \\
\text { 8. Alto porcentaje de Cartera } \\
\text { 9. Falta de gestión }\end{array}$ \\
\hline $\begin{array}{l}\text { OPORTUNIDADES } \\
\text { 1. Plan de Ordenamiento Territorial } \\
\text { 2. Zona de frontera } \\
\text { 3. Instituto Geografico Agustin Codazzi } \\
\text { 4. Oficina de Instrumentos Publicos } \\
\text { 5. Acuerdos de Pago }\end{array}$ & $\begin{array}{l}\text { AMENAZAS } \\
\text { 1. Niveles de Ingreso de la Personal } \\
\text { 2. Desempleo } \\
\text { 3. Confianza en el gobierno } \\
\text { 4. Cultura de Pago } \\
\text { 5. Nivel Educativo de la Comunidad } \\
\text { 6. Situación actual comercial del municipio } \\
\text { 7. Costo de los servicios publicos } \\
\text { 8. Preescripción de la deuda }\end{array}$ \\
\hline
\end{tabular}

Fuente: Elaboración Propia

La secretaria de hacienda del Municipio de Pamplona cuenta con 10 funcionarios del cual está adscrita a ella las siguientes dependencias: Oficina de Impuesto predial, Oficina de Industria y comercio, Contabilidad, Presupuesto y punto de caja.

La administración Municipal presenta una tecnología adecuada atendiendo que todas las dependencias están sistematizadas, posee un software (Trasnfor's) que contiene los módulos de administración, impuestos, nomina, contabilidad y presupuesto, informes y almacén, integrados en un solo programa el cual trabaja en red, el programa en mención posee debilidades ya que es 
muy fácil de manipular no cuenta con una buen seguridad donde se pueda garantizar que no se presente corrupción en el recaudo de los impuesto, las demás dependencias como almacén no mantienen una comunicación permanente con esta, generando un desfase entre la contabilidad y la existencia real de los bienes, derechos y deberes.

La oficina de impuesto que es la oficina encargada del recaudo y atención al cliente y/o contribuyente del Impuesto Predial Unificado está ubicada en buen punto ya que es una de las primeras oficinas del centro administrativo, pero no posee un espacio suficiente para atención directa y personalizada al cliente, cuenta con dos funcionarias competentes, en cuanto al acceso a la información del contribuyente del Impuesto Predial Unificado no es del 100\% oportuna debido a que al solicitar información un propietario de un predio acerca de la obligación que tiene con la administración en ocasiones debe traer el último recibo de pago del impuesto para facilitar el proceso, debido a que el banco reporta diario en físico los recibos del recaudo y toca registrar en el sistema manualmente uno a uno por lo que si el banco no reporta, o el funcionario encargado no lo registra, el sistema automáticamente genera al próximo año la obligación. Por eso importante que el contribuyente conserve su recibo de pago.

En cuanto al impuesto de industria y comercio el Municipio de Pamplona no cuenta con una base de datos actualizada de los establecimientos existentes en la ciudad.

La secretaria de Hacienda carece de un manual de procedimientos, una misión y una visión que ayude a lograr los objetivos propuestos por la administración Municipal. 
Cabe señalar que la secretaria de hacienda tiene como estrategia ingresos por concepto del impuesto predial Unificado, descuentos por pronto pago a los contribuyentes que cancelen en los primeros tres meses del año.

\subsection{Políticas de apoyo}

Implementación de un sistema de información el cual sea perfeccionado a tal punto que además de facturar y apoyar el recaudo del impuesto, asista a la gestión y fiscalización de los mismos, permitiendo garantizar la generación de procesos masivos y controlados en la fiscalización y administración de la información.

Emisión de estado de cuentas, facturas y recibos oficiales de pago por diferentes criterios (vigencia actual, vigencias anteriores, pago parcial, pago de cuotas, acuerdos de pago entre otros.)

Implementación de estrictos niveles de control y calidad en el proceso de registros electrónicos de la información.

Manejo control de prescripciones de acuerdo al marco legal.

Solicitar a la administración municipal que realice con la asesoría del Instituto Geográfico Agustín Codazzi una nueva actualización de la formación catastral de todos los predios que este registrado en la base de datos de la Secretaria de Hacienda. 
Cruce de información con la oficina de instrumentos públicos que ayuden a mantener al día la información de los cambios que experimente la propiedad inmueble.

\subsection{Impuesto predial unificado}

\subsubsection{Definición}

Por tratarse de una de las principales fuentes de financiación de los municipios en Colombia, el Impuesto Predial Unificado encuentra una amplia regulación a través de la ley, decretos nacionales, resoluciones del Instituto Geográfico Agustín Codazzi (IGAC) y normatividad municipal.

El impuesto predial se concibe como un tributo directo que grava los predios y bienes raíces ubicados en áreas urbanas, suburbanas o rurales, con o sin edificaciones, en jurisdicción del Municipio de Pamplona. Este tributo tiene como hecho generador la existencia del predio y la propiedad del bien inmueble el día del vencimiento del período fiscal. Este gravamen tiene como base gravable los avalúos catastrales, los cuáles son de competencia del Instituto Geográfico Agustín Codazzi. Este tributo se autorizó por la Ley 14 de 1983, el Decreto 1333 de 1986 y la ley 44 de 1990, así como las normas que las sustituyan o modifiquen. Es mediante el Acuerdo 027 de 2005 y modificado por el acuerdo 042 del 2013, donde se determina la estructura tarifaria de este impuesto, (Tabla 1). Con respecto a la destinación de este tributo, se tiene que "un 50\% se encuentra comprometido con el pago de la deuda Interna, el 1\% se destina a prevención de 
desastres, el $0.5 \%$ sistematización y el $48.5 \%$ restante, está orientado a libre destinación" (Acuerdo 042, 2013).

En cuanto a las definiciones, la normatividad por razones prácticas es mucho más generalizada que la definición del acuerdo 027, aun así la naturaleza y los elementos de fondo se mantienen, es así como queda claro que el impuesto predial, según la ley 1430 del 2011, es un gravamen real que recae sobre los bienes raíces y que podrá hacerse efectivo sobre el predio independientemente de quien sea su propietario.

\subsubsection{Parte legal}

Ley 44 de 1990, crea el impuesto predial unificado y define sus elementos sustantivos (Ley $44,1990)$.

Decreto reglamentario 2388 de 1991, reglamenta la ley 14 de 1983. El decreto extraordinario 1333 de 1986 y la ley 44 de 1990.

Ley 99 de 1993 establece con destino a la protección del medio ambiente y los recursos naturales renovables (Ley 99, 1993 )

Decreto ley 1421 de 1993, introduce el autoevalúo y las bases presuntas mínimas al impuesto predial unificado en el distrito capital (Decreto Ley 1421, 1993). 
Ley 47 de 1993 establece que en la liquidación del Impuesto Predial del Departamento Archipiélago de San Andrés, providencia y Santa Catalina, se podrán considerar factores adicionales. (Ley 47,1993 )

Ley 299 de 1996 la ley sugiere exonerar a los terrenos de propiedad de los jardines botánicos o destinados a estos fines y terrenos de propiedad de entidades estatales (Ley 299 , 1996 ).

Ley 601 de 2000 modifica el autoevalúo y el reajuste de los valores catastrales para el Distrito Capital.

Ley 675 del 2001 establece que el impuesto predial sobre cada bien privado incorpora el correspondiente a los bienes comunes del edificio o conjunto, en proporción al coeficiente de copropiedad respectivo (Ley 675, 2001 ).

Ley 768 del 2002 permite gravar con impuesto predial y complementario, las construcciones, edificaciones o cualquier tipo de mejora sobre bienes de uso público de la nación, cuando por cualquier razón estén en manos de particulares.

Ley 1430 de 2010 amplia el concepto de sujeción pasiva al impuesto predial para cuando se trate de predios o constitutivos de un patrimonio autónomo imponiendo la obligación sobre los respectivos fideicomitentes o beneficiarios del respectivo patrimonio y sobre los tenedores de inmuebles públicos a título de concesión (Ley 1430, 2010 ). 
Ley 1450 modifica el artículo 4 de la ley 44/90 aumentando el rango mínimo de la tarifa del predial, pasando del uno por mil al cinco por mil. Incluye dos nuevos para la determinación de la tarifa: a) el rango de área y b) el avalúo catastral.

\section{HECHO GENERADOR:}

Si bien este elemento del tributo no se encuentra expresamente definido en la normatividad del impuesto predial unificado, se debe revisar la Sentencia C-903 de 2011 de la Corte Constitucional, que establece como hecho generador "la existencia del predio o bien inmueble". A la par de la definición dada por la Corte, para tener total claridad del hecho generador, se debe acudir a la definición de predio que para el efecto estableció el IGAC en la resolución 070 de 2011: "Inmueble no separado por otro bien público o privado, individualizados por matrícula inmobiliaria; así como las mejoras en predio ajeno." El estatuto de rentas del municipio de Pamplona, acuerdo 027 de 2005, comparte, en su artículo tercero, la definición de hecho generador establecida en la Sentencia antes citada y establece:

Hecho Generador: El Impuesto Predial Unificado, es un gravamen real que recae sobre los bienes inmuebles ubicados en el municipio y se genera por la existencia del predio. Lo constituye la posesión o propiedad de un bien inmueble urbano o rural, en cabeza de una persona natural o jurídica, incluidas las personas de derecho público en el Municipio de Pamplona. (Acuerdo municipal 027, 2015) 
Al respecto, es importante señalar que, antes de la expedición de la sentencia de la Corte Constitucional que definió con claridad el hecho generador del impuesto predial unificado, existían dos tendencias de hecho generador, la primera, relacionada con la existencia del predio, y la segunda, que vincula el hecho generador con el registro del predio.

La normatividad antes descrita mantiene un mismo enfoque, al determinar cómo hecho generador que "recae sobre los bienes inmuebles ubicados en la jurisdicción del Municipio y se genera por las existencias del predio." Constituyendo así un mismo hecho generador, que sustenta un cobro categórico.

\section{SUJETO PASIVO}

En relación con los sujetos pasivos, es importante aclarar que estos se encuentran establecidos en su totalidad por las normas de carácter nacional, e incluso, ha sufrido modificaciones recientes, especialmente en la ley 1607 de 2012. A continuación, se hace un paralelo entre el sujeto pasivo que establecen el acuerdo 027 de 2005, con el establecido en las normas nacionales.

Tabla 3. Paralelo entre el acuerdo 027 de 2005 y normas nacionales.

\section{ACUERDO 027 DE 2005 NORMAS NACIONALES}

Sujeto pasivo: el sujeto pasivo del Impuesto - El propietario, poseedor o usufructuario
Predial Unificado, es la persona natural ojurídica, del predio ubicado en la jurisdicción del
(incluidas las entidades públicas) propietaria o municipio o Distrito.
poseedora de predios ubicados en la jurisdicción
del municipio. De Pamplona, También tienen el


todo orden. Responderán conjuntamente por el enajenante y esta obligación no podrá pago del Impuesto, el propietario y el poseedor transferirse al comprador.

del predio. Cuando se trate de predios sometidos al régimen de comunidad serán sujetos pasivos

- En régimen de comunidad lo serán los del gravamen los respectivos propietarios, cada Respectivos comuneros solidariamente. cual en proporción a su cuota, acción o derecho del bien indiviso.

- En propiedad horizontal, el impuesto predial sobre cada bien privado incorpora el

Si el dominio del predio estuviere desmembrado, como en el caso del usufructo, la carga tributaria será satisfecha por el usufructuario.

correspondiente a los bienes comunes del edificio o conjunto, en proporción al Coeficiente de copropiedad respectivo.

Para efectos tributarios, en la enajenación de

- Establecimientos públicos, Empresas inmuebles, la obligación de pago de los Impuestos que graven el bien raíz, corresponderá al enajenante. industriales y comerciales del Estado y Sociedades de economía mixta del orden Nacional. Decreto 1333 de 1986 articulo 194

Los bienes inmuebles de propiedad de los establecimientos públicos, empresas industriales

- Todo bien de uso público será excluido del y comerciales del estado y sociedades de economía mixta del orden nacional podrán ser gravados con el impuesto predial. ( ART. 194 impuesto predial, salvo aquellos que se encuentren expresamente gravados por la Ley. Ley 1450 de 2011 parágrafo 2. art. 23. DECRETO 1333 DE 1986.

- Consorcios, uniones temporales, Periodo de causación: el Impuesto Predial patrimonios autónomos. LEY 1430 DE Unificado se causa el $1^{\circ}$ de enero del respectivo 2010 año gravable.

- Tenedores de inmuebles públicos a título de concesión. LEY 1430 DE 2010 
- Patrimonios autónomos: Fideicomitentes y/o beneficiarios. LEY 1430 DE 2010

- Consorcios, socios o participes de los consorcios, uniones temporales: Representante de la forma contractual. LEY 1430 DE 2010.

- Bienes de uso público y obra de infraestructura continuarán excluidos, excepto las áreas ocupadas por establecimientos mercantiles. LEY 1607 DE 2012

- Los tenedores a título de arrendamiento, uso, usufructo u otra forma de explotación comercial que se haga mediante establecimiento mercantil dentro de las áreas objeto del contrato de concesión correspondientes a puertos aéreos y marítimos. LEY 1607 DE 2012

- Gravamen real: Podrá hacerse efectivo con el respectivo predio independientemente de quien sea su propietario, sin perjuicio de que el acto de liquidación se dirija al obligado para la respectiva vigencia. LEY 1430 DE 2010. 
Con respecto a la calidad de sujeto pasivo, es evidente que la modificación descrita por el artículo 177 de la Ley 1607 de 2012, genera un marco normativo mucho más amplio, mas descriptivo, y puntual; a diferencia de la normatividad Municipal que es mucho más limitada, a los propietarios, poseedores, personas jurídicas o naturales de los bienes sobre los que recae el impuesto.

\subsubsection{Criterios para definir tarifas del impuesto predial}

La normatividad del Impuesto Predial Unificado, establece unos límites bien definidos a efectos de establecer la tarifa aplicable, y es, dentro de los rangos establecidos por ley, que se mueve la competencia de las entidades territoriales, toda vez que no pueden existir tarifas inferiores o superiores a las establecidas.

Como se mencionó anteriormente las tarifas del impuesto predial son definidas por los Concejos Municipales dentro de un rango que oscila entre el 1 y el 16 por mil, con excepción de los lotes urbanizados no edificados y urbanizables no urbanizados, cuya tarifa puede alcanzar hasta el 33 por mil. En la práctica, los Concejos asignan estas tarifas teniendo en cuenta una gama amplia de criterios, que varían entre los diferentes municipios del país. Los criterios más comunes son:

Rangos de avalúo calculados a partir de salarios mínimos.

- Tarifas únicas por municipios o por tipo de predio, bien sea urbano o rural. 
- Destino económico o uso del predio (por ejemplo, industrial, comercial, institucional, residencial, lotes).

- Rangos de área (hectáreas) para predios rurales.

- Rangos de avalúos (por tamaño o valor) para predios urbanos.

- Estratos socioeconómicos para el sector residencial urbano (en algunos municipios se utiliza la estratificación para predios comerciales e industriales).

Las tarifas no se establecen para un período determinado ya que su vigencia depende de los Consejos Municipales. En algunos casos, las tarifas han estado vigentes por más de 10 años.

\subsubsection{Imposición de tarifas del impuesto predial.}

En cuanto al mecanismo de imposición de tarifas del impuesto predial por parte del concejo municipal esta se hace sujeta a la Constitución y la ley 44 de 1990. Las tarifas se implementan en los rangos ahí establecidos y se fijan mediante el estatuto tributario municipal que en el caso de Pamplona es el acuerdo 027 del 2005, Ocaña es el acuerdo No. 42 de 2009 y Tunja es el Decreto 389 del 2006. Debido a la sensibilidad que genera el tema de impuestos y más aún el incremento de la tarifa de estos, no todos los gobiernos municipales modifican al estatuto tributario debido al peso político que implican estas decisiones y que pueden afectar la gobernabilidad.

En el Municipio de Pamplona, en su estatuto Tributario Territorial el Concejo Municipal estipula las tarifas del impuesto predial por estrato socio económico, predios urbanos económicos, 
edificados no residenciales, predios no edificados, predios rurales, predios rurales con destinación económica.

Tabla 4. Estructura tarifario Impuesto Predial Unificado Municipio de Pamplona

\begin{tabular}{|c|c|}
\hline ESTRATO & TARIFA \\
\hline 1 & $7 \times 1000$ \\
\hline 2 & $8 \times 1000$ \\
\hline 3 & $9 \times 1000$ \\
\hline 4 & $11 \times 1000$ \\
\hline 5 & $14 \times 1000$ \\
\hline EDIFICACION AMENAZA DE RUINA & $16 \times 1000$ \\
\hline \multicolumn{2}{|c|}{$\begin{array}{c}\text { PREDIOS URBANOS ECONOMICOS Y OTRAS ACTIVIDADES } \\
\text { ECONOMICAS, EDIFICADOS NO RESIDENCIALES }\end{array}$} \\
\hline INMUEBLES INDUSTRIALES & $7 \times 1000$ \\
\hline INMUEBLES COMERCIALES & $10 \times 1000$ \\
\hline NMUEBLES SERVICIOS & $12 \times 1000$ \\
\hline INMUEBLES SECTOR FINANCIERO & $16 \times 1000$ \\
\hline INMUEBLES DESTINACIÓN MIXTA & $12 \times 1000$ \\
\hline \multicolumn{2}{|l|}{ PREDIOS URBANOS - NO EDIFICADOS } \\
\hline $\begin{array}{l}\text { Predios urbanizaboles no urbanizados y urbanbizados no } \\
\text { edificados dentro del perimetro urbano con avaluo } \\
\text { catastratal superior a } 50 \text { SMMLV }\end{array}$ & $20 \times 1000$ \\
\hline $\begin{array}{l}\text { Predios urbanizables no urbanizados y urbanizados no } \\
\text { edificados dentro del perimetro urbano con avaluo } \\
\text { catastral inferior a } 50 \text { SMMLV }\end{array}$ & $15 \times 1000$ \\
\hline Predios Urbanos no urbanizables & $10 \times 1000$ \\
\hline \multicolumn{2}{|l|}{ PREDIOS RURALES } \\
\hline Predios Rurales Menores a 20 Hectareas & $7 \times 1000$ \\
\hline Predios Rurales mayores de 20 Hectareas & $10 \times 1000$ \\
\hline \multicolumn{2}{|c|}{ PREDIOS RURALES CON DESTINACIÓN ECONÓMICA } \\
\hline Predios destinados al turismo, recreación y servicios & $16 \times 1000$ \\
\hline $\begin{array}{l}\text { Predios destinados a instalaciones y montaje de } \\
\text { equipos para explotación agroindustrial y pecuaria }\end{array}$ & $15 \times 1000$ \\
\hline $\begin{array}{l}\text { Predios destinados a intalaciones montaje de equipo } \\
\text { para la extración y explotación de minerales e } \\
\text { hidrocarburos. Industria los predios donde se extrae } \\
\text { arcilla, blastro, arena o cualquier otro material para } \\
\text { construcción }\end{array}$ & $16 \times 1000$ \\
\hline $\begin{array}{l}\text { Parcelaciones, finca de recreo condominios, conjuntos } \\
\text { residenciales cerrados o urbanizaciones campestres }\end{array}$ & $16 \times 1000$ \\
\hline
\end{tabular}

Fuente: Elaboración Propia 
Para el caso del Municipio de Ocaña, en su Estatuto Tributario Municipal, el Concejo

Municipal dispone una distribución de tarifas según diferentes características: sector vivienda

(estratificada y no estratificada), sector comercial y de servicios, sector industrial, financiero, predios cívicos institucionales, sector rural y otros.

Tabla 5. Estructura tarifario Impuesto Predial Unificado Municipio de Ocaña

\begin{tabular}{|c|c|}
\hline \multicolumn{2}{|l|}{ PARA EL SECTOR VIVIENDA } \\
\hline ESTRATIFICACIÓN & TARFIAS SOBRE AVALUO \\
\hline ESTRATO UNO (1) & $5.2 \times 1000$ \\
\hline ESTRATO DOS (2) & $5.4 \times 1000$ \\
\hline ESTRATO TRES (3) & $5.5 \times 1000$ \\
\hline ESTRATO CUATRO (4) & $5.6 \times 1000$ \\
\hline ESTRATO CINCO Y SEIS (5 Y 6) & $6.0 \times 1000$ \\
\hline \multicolumn{2}{|c|}{ PREDIOS URBANOS NO ESTRATIFICADOS } \\
\hline BASE GRAVEBLE (EN UVT) & TARIFAS \\
\hline DE 1 A 546 & 5.1 POR MIL \\
\hline DE 547 A 1.090 & 5.2 POR MIL \\
\hline DE 1.0921 A 1.820 & 5.4 POR MIL \\
\hline DE 1.821 A 2.910 & 5.6 POR MIL \\
\hline DE 2.911 EN ADELANTE & 6.0 POR MIL \\
\hline \multicolumn{2}{|c|}{ PREDIOS CON USO COMERCIL Y DE SERVICIOS } \\
\hline URBANOS & 6.5 POR MIL \\
\hline RURALES & 6.0 POR MIL \\
\hline \multicolumn{2}{|l|}{ CON USO INDUTRIAL } \\
\hline URBANO INDUSTRIAL & 7.5 POR MIL \\
\hline RURALES INDUSTRIALES & 6.0 POR MIL \\
\hline \multicolumn{2}{|l|}{ SECTOR FINANCIERO } \\
\hline $\begin{array}{l}\text { Predios en los que funciones entidades del sector } \\
\text { financiero, sometida al control de la } \\
\text { superintendencia Financiera }\end{array}$ & 16 POR MIL \\
\hline $\begin{array}{l}\text { Establecimientos Educativos privados en sus } \\
\text { diretentes niveles de escolaridad y educación } \\
\text { especial }\end{array}$ & 5.0 POR MIL \\
\hline $\begin{array}{l}\text { Predios donde funcione la prestación de servicios } \\
\text { necesarios para la población como soporte de sus } \\
\text { actividades como: Culturales, Deportivas, } \\
\text { Asistenciales y de Culto. }\end{array}$ & 10 POR MIL \\
\hline $\begin{array}{l}\text { Predios donde se desarrollen actividades públicas, } \\
\text { judiciales, notariales y administrativas, de educación } \\
\text { técnica y superior, Estaciones y Subestaciones de } \\
\text { Policía, Carceles y Guarniciones Militares }\end{array}$ & 12 POR MIL \\
\hline \multicolumn{2}{|l|}{ RURALES } \\
\hline $\begin{array}{l}\text { Rurales con exploración o explotación minera o de } \\
\text { hidrocarburos }\end{array}$ & 14 POR MIL \\
\hline \multicolumn{2}{|l|}{ DEMAS PREDIOS RURALES } \\
\hline BASE GRAVEBLE (EN UVT) & TARIFAS \\
\hline DE O A 546 & 5.0 POR MIL \\
\hline DE 547 A 1.090 & 5.1 POR MIL \\
\hline DE 1.091 A 2.547 & 5.2 POR MIL \\
\hline DE 2.548 A 3.275 & 5.3 POR MIL \\
\hline DE 3.276 EN ADELANTE & 5.5 POR MIL \\
\hline \multicolumn{2}{|l|}{ OTROS } \\
\hline $\begin{array}{l}\text { Predios afectados por el Plan de Ordenamiento } \\
\text { Territorial y aquellos que tienen cargas } \\
\text { arquitectonicas de conservación }\end{array}$ & 5.0 POR MIL \\
\hline \multicolumn{2}{|c|}{ PREDIOS NO EDIFICADOS SECTOR URBANO } \\
\hline Predios urbanos no construidos & 20 POR MIL \\
\hline $\begin{array}{l}\text { Predios afectados como Zona de Riesgo o declarados } \\
\text { de utilidad Pública }\end{array}$ & 5 POR MIL \\
\hline
\end{tabular}

Fuente: Elaboración Propia 
Tunja su estatuto tributario el concejo municipal aprueba una tarifas por estrato económico en cuanto a vivienda, comerciales, industriales, servicios, financieros, mixtos, predios rurales, urbanos edificados y no edificados.

Tabla 6. Estructura tarifario Impuesto Predial Unificado Municipio de Tunja Boyacá

\begin{tabular}{|c|c|}
\hline \multicolumn{2}{|l|}{ PREDIOS URBANOS - VIVIENDA } \\
\hline ESTRATO & TARIFA \\
\hline 1 & $4.5 \times 1000$ \\
\hline 2 & $6.0 \times 1000$ \\
\hline 3 & $7.25 \times 1000$ \\
\hline 4 & $8.25 \times 1000$ \\
\hline 5 & $9.0 \times 1000$ \\
\hline 6 & $11 \times 1000$ \\
\hline \multicolumn{2}{|l|}{ COMERCIALES, INDUSTRIALES, SERVICIOS Y FINANCIEROS } \\
\hline Hasta el valor $\$ 10^{\prime} 000.0005$ por mil & 5 por mil \\
\hline Desde el valor de $\$ 10^{\prime} 000.001$ Hasta $\$ 30^{\prime} 000.0007 .5$ por mil & 7.5 por mil \\
\hline Desde el valor de $\$ 30^{\prime} 000.001$ Hasta $\$ 50^{\prime} 000.00010 .5$ por mil & 10.5 por mil \\
\hline Desde el valor de $\$ 50^{\prime} 000.001$ Hasta $\$ 100^{\prime} 000.00011 .5$ por mil & 11.5 por mil \\
\hline Desde el valor de $\$ 100^{\prime} 000.001$ Hasta $\$ 200^{\prime} 000.00012$ por mil & 12 por mil \\
\hline Desde el valor de $\$ 200^{\prime} 000.001$ en adelante 15 por mil & 15 por mil \\
\hline \multicolumn{2}{|l|}{ MIXTOS } \\
\hline Hasta el valor $\$ 10^{\prime} 000.0005$ por mil & 7 por mil \\
\hline Desde el valor de $\$ 10^{\prime} 000.001$ Hasta $\$ 30^{\prime} 000.0007 .5$ por mil & 9.5 por mil \\
\hline Desde el valor de $\$ 30^{\prime} 000.001$ Hasta $\$ 50^{\prime} 000.00010 .5$ por mil & 11.5 por mil \\
\hline Desde el valor de $\$ 50^{\prime} 000.001$ Hasta $\$ 100^{\prime} 000.00011 .5$ por mil & 13.5 por mil \\
\hline Desde el valor de $\$ 100^{\prime} 000.001$ en adelante 15 por mil & 15 por mil \\
\hline \multicolumn{2}{|l|}{\begin{tabular}{|l} 
PREDIOS URBANIZABLES NO URBANIZADOS \\
\end{tabular}} \\
\hline Hasta el valor $\$ 30^{\prime} 000.00011$ por mil & 11 por mil \\
\hline Desde el valor de $\$ 30^{\prime} 000.001$ Hasta $\$ 50^{\prime} 000.00015$ por mil & 15 por mil \\
\hline Desde el valor de $\$ 50 .^{\prime} 000.001$ Hasta $\$ 100^{\prime} 000.00018$ por mil & 18 por mil \\
\hline Desde el valor de $\$ 100^{\prime} 000.001$ Hasta $\$ 200^{\prime} 000.00020$ por mil & 20 por mil \\
\hline Desde el valor de $\$ 200^{\prime} 000.001$ en adelante & 21 por mil \\
\hline \multicolumn{2}{|l|}{ PREDIOS URBANOS - NO EDIFICADOS } \\
\hline Hasta 200 metros cuadrados 12 por mil & 12 por mil \\
\hline De 201 a 1000 metros cuadrados 14 por mil & 14 por mil \\
\hline Mayor a 1001 metros cuadrados & 16 por mil \\
\hline \multicolumn{2}{|l|}{ PREDIOS RURALES } \\
\hline Predios Inferios a 100 SMLV & 4.5 por mil \\
\hline Predios Superior a 100 y menor a 150 SMLV & 5 por mil \\
\hline Predios Igual o superior a 150 SMLV & 10 por mil \\
\hline Predios destinados a Turismo Recreacion y Servicios & 14 por mil \\
\hline $\begin{array}{l}\text { Predios destinados a la eplotación minera arena y materiales para } \\
\text { la construccion }\end{array}$ & 10 por mil \\
\hline $\begin{array}{l}\text { Parcelaciones, fincas de recreo, condominios, conjuntos } \\
\text { residenciales, cerrados y centros vacacionales }\end{array}$ & 16 por mil \\
\hline Cualquier valor del avalúo & 4 por mil \\
\hline
\end{tabular}

Fuente: Elaboración Propia 
Según la comparación de los predios Urbanos de Vivienda de los Municipios de Pamplona, Ocaña y Tunja, las tarifas más altas son del municipio de Pamplona donde su tarifa mínima es del 7x1000 y la más alta 16x1000, Tunja aplica unos tarifas menos elevadas según el estrato, donde su tarifa mínima es del 4.5 x mil, y frente a Ocaña se manejan las tarifas más cómodas, en todos los estratos.

En los predios destinados al comercio cada Municipio establece sus bases para establecer sus tarifas, en donde Pamplona define sus tarifas de acuerdo al Sector Económico, si es Industrial, comercial, de Servicios o Financiero, Ocaña establece sus tarifas dependiendo si el predio es Urbano o Rural, Tunja maneja las tarifas de acuerdo a un rango del valor del avaluó sea cual fuera el sector Económico, donde su mayor tarifa es del 15 x 1000.

En los predios Urbanos no edificados, establece unos salarios mínimos según el avaluó catastral donde su mayor tarifa es del 20 x 1000, Ocaña, maneja dos bases que son predios no construidos con una única tarifa del 20 x 1000 y predios afectados o en zona de riesgo con una tarifa del 5 x 1000 y Tunja maneja sus tarifas por metros cuadrados.

Frente a los predios rurales el Municipio de Pamplona establece sus tarifas dependiendo si el predio es mayor o menor a 20 hectáreas, donde su mínima tarifa es del 7 x1000 frente a Tunja que es del 4.5 x 1000 y su tarifa máxima es del 16 x 1000 para ambos Municipios, mientras que Ocaña maneja unas bases sobre UVTS. Y sus tarifas son más cómodas. 
Predios sujetos a afectación definidas en el plan de ordenamiento territorial Ocaña y Tunja tiene especificado este grupo a una tarifa del 4 por mil Pamplona no tiene especificado este grupo.

\subsubsection{Exenciones del Impuesto Predial Unificado}

En cuanto a las exenciones la ley Nacional es la que faculta a los Concejos Municipales para determinar los predios a quienes pueden determinar cómo exento y los porcentajes en que se realizaran dichas exenciones. Para el Municipio de Pamplona, las exenciones son las antes mencionadas, que van desde el 50 al 100\% del valor sobre el concepto de Impuesto Predial. Dichos bienes son entonces, aquellos que están exentos en virtud de tratados internacionales, los inmuebles propiedad del Municipio, propiedad de Cruz Roja, Bomberos, Hogares comunitarios, Los predios destinados a asilos, orfanatos predios de propiedad de las instituciones que prestan el servicio de educación pública, propiedad de las juntas de acción comunal, de la iglesia y aquellos declarados bienes de interés cultural de carácter municipal, Departamental o Nacional.

Para ser beneficiarios de estos descuentos, es necesario que ante la Secretaria de Hacienda allegue la siguiente documentación, según cada tipo de bien que tiene derecho al descuento:

- Propiedad de Cruz Roja: resolución de declaración de la cruz roja.

- Bomberos: certificación de planeación

- Hogares comunitarios: resolución de personería jurídica de la representante legal, posterior certificación de la misma sobre el uso del inmueble determinada.

- Los predios destinados a asilos, orfanatos: certificación de planeación 
- Predios de propiedad de las instituciones que prestan el servicio de educación pública: certificación del ministerio como institución educativa y certificación de planeación sobre el uso del inmueble.

- Propiedad de las juntas de acción comunal, certificación de la secretaria de desarrollo social y comunitario.

- Propiedad de la iglesia, certificación de planeación.

- Aquellos declarados bienes de interés cultural de carácter municipal, Departamental o Nacional, los predios determinados en el plan de ordenamiento territorial o lo determinados así por decreto municipal, departamental o nacional, copia de acto administrativo, o certificación de planeación.

Tabla 7. Predios exentos del impuesto predial

\section{PREDIOS EXENTOS DEL IMPUESTO PREDIAL}

\section{PAMPLONA TUNJA OCAÑA}

a. Los predios que deben recibir tratamiento de exentos en virtud de tratados internacionales. $100 \% \quad 100 \%$

b. Los bienes inmuebles de propiedad del Municipio.

$100 \% \quad 100 \% \quad 100 \%$

c. Los predios de propiedad de Cruz Roja, Bomberos (Art. 10 Ley 322/96) y Defensa $\quad 100 \% \quad 100 \% \quad 100 \%$ Civil.

d. Hogares comunitarios que su destinación esté debidamente certificada por el ICBF. $50 \% \quad 100 \% \quad 100 \%$

e. Los predios destinados a asilos, orfanatos (Para los Predios Exclusivamente destinados a este $100 \% \quad 100 \% \quad 100 \%$ fin), albergues, guarderías infantiles, siempre 


\section{PREDIOS EXENTOS DEL IMPUESTO PREDIAL

que sean entidades sin ánimo de lucro y

legalmente reconocidas.

f. Los predios de propiedad de las instituciones que prestan el servicio de educación pública, exclusivamente en los predios destinados para la $100 \% \quad 100 \% \quad 100 \%$ labor educativa.

g. Los bienes inmuebles de propiedad de las juntas de acción comunal destinadas a uso exclusivo de las actividades propias comunales (debidamente certificado por la asociación comunal $\mathrm{Y}$ $\begin{array}{lllll}\text { Planeación Municipal.) polideportivos, los } \quad 100 \% & 100 \% & 100 \%\end{array}$ predios plenamente reconocidos como parques públicos de propiedad del Municipio (Art. 137, Ley 488/98) y puestos de salud, debidamente reconocidos. $100 \%$

h. Exonérese a los inmuebles de propiedad de la iglesia católica destinados al culto y vivienda de las comunidades religiosas, a las curias Diocesanas, casas episcopales y curales, y seminarios conciliares, lo mismo que los inmuebles de propiedad de otras iglesias diferentes a la católica reconocidas por el estado colombiano y que tengan el mismo uso; y los $100 \% \quad 100 \% \quad 100 \%$ incluidos como tales en el Plan de Básico de Ordenamiento Territorial. en cuanto a las demás propiedades de las iglesias o comunidades religiosas o áreas con destinación diferente serán gravadas en la misma forma que las de los particulares ( 133/94, Art. 7) 


\section{PREDIOS EXENTOS DEL IMPUESTO PREDIAL}

\section{PAMPLONA TUNJA OCAÑA}

i. Los inmuebles de propiedad de las iglesias, reconocidas por el Estado Colombiano, en cuanto a las áreas estimadas al culto. Los demás predios a áreas $100 \% \quad 100 \%$ con destinación diferente serán gravados con el Impuesto Predial Unificado

J Los predios declarados bienes de interés cultural de carácter municipal, Departamental o $100 \%$ $100 \% \quad 100 \%$ Nacional, previo concepto del de la Autoridad Cultural Competente que Certifique que cumplan con los requisitos de conservación, valoración y mantenimiento del Patrimonio cultural arquitectónico. Los Predios Públicos $\quad 50 \%$ serán exentos en 100\%, y los predios Particulares en un 50\%, así mismo los museos serán exentos en el $100 \%$ por Predial Unificado.

\begin{tabular}{|c|c|c|}
\hline $\begin{array}{l}\text { Conservación Monumental serán exentos del } \\
\text { impuesto predial }\end{array}$ & $80 \%$ & \\
\hline $\begin{array}{l}\text { Las tumbas y bóvedas de los cementerios, } \\
\text { siempre y cuando estén en cabeza de personas } \\
\text { naturales, no tengan ánimo de lucro respecto }\end{array}$ & $100 \%$ & $100 \%$ \\
\hline
\end{tabular}




\subsubsection{Lineamientos del Impuesto Predial Unificado.}

En la próxima actualización catastral, la alcaldía debe promover que el Instituto Geográfico Agustín Codazzi con el apoyo de los catastros descentralizados realice la actualización, acorde al artículo 24 de la ley 1450 de 2011, que le permita al municipio emitir cobros sobre el valor real de los predios.

La alcaldía debe promover el compromiso legal y cívico de los contribuyentes con la ciudad, fortaleciendo así estas importantes variables determinantes del pago y que inciden fuertemente en el recaudo para lograr mayores contribuciones en el mismo.

La secretaría de hacienda municipal debe fortalecer la publicidad de modo que lleguen a todos los contribuyentes y continuar con las campañas de ofertas y descuentos por el pago que han tenido gran acogida.

La alcaldía debe mejorar la imagen que perciben los contribuyentes de corrupción en el uso de los impuestos informando a la ciudadanía de la destinación y uso efectivo de los tributos recaudados. De esta manera, debilitará una de los determinantes incidentes entre quienes no pagan el impuesto mejorando así el recaudo de los mismos.

Debido a que el nivel de escolaridad incide fuertemente en el pago oportuno del impuesto predial, deben realizarse jornadas académicas de formación ciudadana donde los contribuyentes de baja escolaridad se identifiquen como actores importantes dentro de las dinámicas de la ciudad, 
como poseedores de unos derechos y así mismo responsables de cumplir con unos deberes, dentro de los cuales está la responsabilidad tributaria con el municipio.

Se debe mejorar la imagen del proceso de pago la cual no es favorable para los contribuyentes, ya sea adoptando medidas en la atención al contribuyente o con la entrega en el domicilio del recibo del impuesto predial, el cual anteriormente llegaba a las casas, entrega que ahora no se realiza.

Si bien los contribuyentes considera que la tarifa del impuesto predial en el municipio es alta, el municipio debe acatar la ley 1450 de 2011 en su artículo 23 e incrementar las tarifas del impuesto predial unificado a un mínimo de $5 \%$ con el fin de fortalecer el monto de sus ingresos propios como parte de los ingresos totales.

Se debe hacer sentir al ciudadano como benefactor/beneficiario con el pago de sus impuestos. Como ya se mencionó, se debe fortalecer el compromiso con el pago de impuesto para el mejoramiento de la ciudad, pero así mismo, se debe evidenciar con inversiones públicas como el contribuyente está siendo beneficiado como ciudadano con el uso del recaudo de sus impuestos. 


\subsection{Impuesto industria y comercio}

\subsubsection{Definición}

Es un tributo de carácter municipal, directo, que grava a las personas naturales o jurídicas y a las sociedades de hecho en desarrollo de actividades industriales, comerciales y de servicios y cuyo producto se destina a atender los servicios públicos y las necesidades colectivas de la respectiva entidad territorial.

\subsubsection{Leyes}

- Ley 56 de 1981 decreto reglamentario 2024 de 1982; define la base gravable para las entidades propietarias de obras para generación de energía eléctrica (Ley 56 , 1981 ).

- Ley 14 de 1983 decreto ley 1333 de 1986; define los elementos del impuesto (Ley 14 , 1983 )

- Decreto reglamentario 3070 de 1983; obligación de registrar su actividad en cada Municipio y llevar registros contables.

- Ley 43 de 1987; establece el anticipo de hasta el cuarenta por ciento (40\%) del Impuesto de Industria y Comercio. (Ley 43,1987 ) 
- Ley 49 de 1990; Define la regla de territorialidad para la actividad industrial. (Se tributa a favor del Municipio donde se encuentra ubicada la cede fabril por el total de ingresos que se perciban por la comercialización de la producción.

- Ley 142 de 1994; establece que las empresas de servicios públicos pueden ser gravadas con el Impuesto de Industria y Comercio.

- Ley 383 de 1997; Define la causación y la base gravable para los servicios públicos domiciliados y para los distribuidores de combustible.

- Ley 633 de 2000; Interpreta el carácter administrativo de las actividades desarrolladas por la Nación, sus establecimientos Públicos, superintendencias y unidades administrativas especiales del orden nacional.

- Define la distribución de los ingresos en el transporte terrestre automotor.

- Ley 675 del 2001, Excluye del impuesto de industria y comercio a las personas jurídicas originada en la construcción de la propiedad horizontal.

- Ley 863 de 2003, Define la distribución de los ingresos en las cooperativas de Trabajo Asociado.

- Decreto ley 1421 de 1993, define el régimen para Bogotá con las siguientes características: 
I. Periodo de causación bimestral.

II. Definición para precisar los ingresos de los industriales y el hecho generador para la actividad de servicios.

III. Definición de la base gravable sobre ingresos netos y rango de tarifas entre el dos por mil (2.0/00) y e treinta por mil 30.0/00);

IV. Autoriza la adopción de sistema de retenciones y la definición de bases presuntas mínimas;

V. Autoriza imponer el gravamen a los profesionales independientes.

- Ley 1430 del 2010, establece una regla especial de base gravable de las empresas de servicios temporales sobre los ingresos brutos, entendiendo por esto el valor del servicio de colaboración temporal menos los salarios, seguridad social, parafiscales, indemnizaciones y prestaciones sociales de los trabajadores en mención.

A través del Articulo 52 se adiciono el artículo 42 de la ley 14 de 1983 incluyendo como parte de la base gravable especial para el sector financiero los ingresos varios. Para los comisionistas de bolsa, la base impositiva será la establecida por los bancos en los rubros pertinentes. 


\subsubsection{Economía en el municipio de pamplona}

La Economía de Pamplona se fundamenta en el Comercio y en los Servicios dado que el sector industrial señala un escaso desarrollo de tal forma que aproximadamente el $85 \%$ de los establecimientos se dedican al comercio empleando para ello el 37\% de personal ocupado en el área urbana.

Predominan empresas de tamaño microempresarial que en promedio no alcanzan las tres personas por establecimiento, debilidad que es corroborada con el hecho de que solo el $2 \%$ aproximado de los negocios hagan sus ventas al por mayor y que más del $55 \%$ de los establecimientos carezcan de licencia de funcionamiento por parte de la Alcaldía Municipal.

La Cámara de Comercio de Pamplona dispone de información correspondiente al total de establecimientos inscritos por actividad económica que indican la estructura de la actividad productiva y comercial del municipio y su participación en la economía local.

Tabla 8. Total de empresas inscritas por actividad económica

DICIEMBRE /95

\section{ACTIVIDAD}

$\mathbf{N}^{\circ}$ TOTAL EMPRESAS

1. Agricultura, Caza y Silvicultura.

2. Explotación de minas y canteras.

3. Industria Manufacturera.

4. Electricidad, Gas y Vapor.
PARTICIPACIÓN

8

2

0.46

111

0.12

6.29

10

0.57 


\begin{tabular}{llcc}
\hline \multicolumn{1}{c}{ ACTIVIDAD } & N TOTAL & PARTICIPACIÓN \\
& & EMPRESAS & \% \\
\hline 5. $\begin{array}{l}\text { Industria de la Construcción. } \\
\text { 6. Comercio en General. }\end{array}$ & 19 & 1.08 \\
7. $\begin{array}{l}\text { Transporte, Almacenamiento } \\
\text { Comunicaciones. }\end{array}$ & y & 22 & 85.42 \\
8. & Establecimientos Financieros. & 8 & 1.25 \\
9. Servicios Comunales, Sociales & $\mathrm{y}$ & 77 & 0.45 \\
& Personales. & & 4.37 \\
\hline TOTAL & $\mathbf{1 . 7 6 3}$ & $\mathbf{1 0 0 . 0}$ \\
\hline
\end{tabular}

Fuente: Cámara de Comercio Pamplona

Se desprende del cuadro anterior un notable predominio de establecimientos de comercio que alcanza el $85.42 \%$ del total. El segundo lugar es ocupado los establecimientos manufactureros con un 6.29\%, el tercer lugar en los registros de establecimientos de la Cámara de Comercio local está representado por el sector de los servicios conformado por los servicios comunales, sociales y personales. (Salud, Educación, Asesorías, Entidades Gubernamentales, etc.), establecimientos financieros (Bancos, CAV, Seguros etc.) y transporte, almacenamiento y comunicaciones.

A continuación se reseña de forma general la situación de la economía pamplonesa mediante una descripción subsectorial donde se agrupan las principales actividades industriales, comerciales y de servicios.

- La producción manufacturera es una actividad económica que representa menos del 10\% de los establecimientos y del empleo de la ciudad. La tercera parte de la industria corresponde a la producción de tejidos de los cuales la mayoría de ellos adelantan sus 
procesos en forma manual. El Segundo renglón es el de Producción de Alimentos particularmente de panaderías, dulcerías y salsamentarias.

- Las industrias existentes se caracterizan por su condición microempresarial derivada del poco capital invertido, su retraso productivo en que no ha mayor división social del trabajo, el predominio de la producción “artesanal” y la poca acumulación de capital. En promedio la industria sólo ocupa 2.3 empleados por establecimiento y muchos de ellos hacen parte de la economía informal ya que del sector sólo el $20 \%$ tienen licencia de funcionamiento.

- Además el sector se debate en medio de un mercado local estrecho debilitando en su expansión y desarrollo por la crisis económica de Venezuela y del relativo aislamiento de otros municipios y centros de poder departamental: por esto a la falta de organización del gremio industrial se suma su escasa participación en el proceso de integración regional fronteriza.

La Cámara de Comercio de Pamplona registra 111 establecimientos industriales, distribuidos como se registra a continuación y sobre los cuales se debe señalar que el (43.25\%) son productores de alimentos.

Tabla 9. Composición de la industria de Pamplona

\begin{tabular}{lcc}
\hline \multicolumn{1}{c}{ ACTIVIDAD } & NÚMERO DE & REPRESENTATIVIDAD \\
& EMPRESAS & $\%$ \\
\hline INSCRITAS & 43.25 \\
Productos Alimenticios & 48 & 26.13 \\
Calzado y Cueros & 29 & 0,90 \\
\hline
\end{tabular}




\begin{tabular}{lcc}
\hline \multicolumn{1}{c}{ ACTIVIDAD } & NÚMERO DE & REPRESENTATIVIDAD \\
& EMPRESAS & $\%$ \\
INSCRITAS & 13.52 \\
Maderas y Muebles & 15 & 4.50 \\
Editoriales e Imprentas & 5 & 6.30 \\
Minerales no metálicos & 7 & 5.40 \\
Industrias Metalmecánicas & 6 & $\mathbf{1 0 0 , 0}$ \\
\hline TOTAL INDUSTRIA & $\mathbf{1 1 1}$ & \\
\hline
\end{tabular}

Fuente: Cámara de Comercio Pamplona 2001

En cuanto a la producción de alimentos se destacan las panaderías, fábricas de dulces, salsamentarias y lácteos (Quesos y Yogurt). En cuanto al sector de confección de prendas de vestir, aunque solo se encuentran registrados 29 establecimientos, según censo comercial realizado por la Cámara de Comercio de Pamplona en el Primer semestre del año 1999, se han detectado más de 150 empresas informales de tejido manual, tejido industrial y otras confecciones que representan la actividad económica que por tradición y costumbres más se ha practicado en el municipio y que a causa de una falta de organización, mejoramiento de procesos y a la ausencia de políticas definidas de comercialización, no ha tenido el desarrollo que se merece. Otra industrias que se han sostenido en Pamplona son la metalmecánica (talleres de ornamentación), productos minerales no metálicos (tejas, baldosines y artesanías), y maderas y muebles (carpinterías y ebanisterías).

Aproximadamente 1506 establecimientos se encuentran registrados como comerciantes, de los cuales el 2\% aproximado corresponde a comercio al por mayor. La gran mayoría, representada en el $92.7 \%$ son de comercio al detal y $5.31 \%$ se dedican a actividades de hotelería, restaurantes y otras actividades de turismo. Como se ha mencionado, el comercio congrega mayor número de 
negocios de la cabecera municipal pero sin que ello signifique una mayor fortaleza frente a otros sectores ya que en promedio solo ocupa 1.5 empleados por establecimiento, mientras que los servicios, por ejemplo, contabilizan cinco trabajadores en promedio. Además casi la mitad de los negocios comerciales son "tiendas" que, aunque constituyen un importante sector en cuanto facilitan la distribución de bienes de la canasta familiar, no generan mayor empleo, ni permiten acumulación ampliada de capital, base de cualquier economía de mercado.

Otros establecimientos comerciales importantes son los especializados en alimentos (bodegas, supermercados, heladerías) y los almacenes de vestuario, muebles y materiales de construcción.

Se aprecia que el sector viene creciendo de manera desorganizada puesto que proliferan negocios sin mayor regulación (60.29\% carece de licencia de funcionamiento) agudizando una competencia que no beneficie a nadie en particular y por el contrario, disuade las posibilidades de inversión. Manifestación de este fenómeno se encuentra en que a pesar de la caída en las ventas, de la escasez del crédito y de la falta de capacitación, los comerciantes no tienen interés por crear o fortalecer asociaciones que podrían interpretar sus intereses gremiales.

Dada su poca actividad productiva se deduce que buena parte el comercio se limita a la reventa de mercancías traídas de otras regiones; como hemos dicho, son negocios de tamaño pequeño localizados en el centro de la ciudad y cuya actividad va desde la especializada de calzado, electrodomésticos, vestuario, farmacia, repuestos para automotores, materiales de construcción. 
Las dificultades del sector se acentuaron desde la crisis del bolívar en 1983 pues Pamplona sostenía su comercio de la afluencia de turistas venezolanos que con el deterioro de su moneda han prácticamente desaparecido del mercado local.

El sector de los servicios es el que mayor número de empleos directos genera en la ciudad al totalizar la mitad del personal ocupado, con un promedio de 5 personas por establecimiento. Sobresalen aquí las dependencias institucionales que agrupan la tercera parte del empleo; y en donde las divisiones departamental y municipal especialmente en el área educativa generan un importante número de empleos directos e indirectos.

Además, existen instituciones como la Universidad de Pamplona y el Instituto Superior de Educación Rural ISER que de igual manera influyen en la economía de la sociedad pamplonesa. Estudio realizado por la Cámara de Comercio de Pamplona en el año 2000 se detectaron la existencia de 204 inmuebles dedicados a prestación de servicios a estudiantes (Alimentación, alojamiento y planchado y lavado) El 90\% de dichos inmuebles son casas de habitación de los cuales el $40 \%$ aproximado son casas alquiladas para ofrecer estos servicios; los valores a los cuales se ofrecen estos servicios oscilan entre 70 y 100 mil pesos por alquiler de habitación o alimentación y entre 100 y 170 mil por alojamiento y alimentación. Otra de las actividades informales son los talleres de mantenimiento, los servicios asistenciales y los profesionales. Las acciones financieras se desarrollan gracias a la presencia de 4 establecimientos de este tipo localizados en el centro de la ciudad. 
Gracias a las restauraciones históricas de los últimos años el municipio posee una gran riqueza arquitectónica expresada en iglesias, museos y casas coloniales Parque Águeda gallardo, Catedral Santa Clara, Santuario del Humilladero, Ermita de las Nieves, Seminario Mayor Santo Tomas de Aquino, Asilo de Ancianos San José, Convento de las Clarisas, Capilla San Juan de Dios, Casa de Encuentros Nazareth, Museo de Arte Religioso, Museo Anzoategui, Museo de Arte Moderno Ramírez Villamizar, Museo Casa Colonial, Casa de Mercado y casa de las Cajas Reales actual sede del servicio Nacional de Aprendizaje que sumadas al ambiente cultural que le rodean, a la programación de eventos y a su agradable clima, le otorgan a Pamplona un especial atractivo turístico.

Sobre el particular se destacan las conmemoraciones de Semana Santa y del Aniversario de la Independencia (4 de Julio), festividades de la Virgen del Carmen (16 de julio) Fiesta del Señor del Humilladero (14 de Septiembre) y las festividades decembrinas, eventos éstos en los que se presenta la mayor afluencia turística. Para su atención se cuenta con 11 hoteles, 95 restaurantes y cafeterías, escenarios deportivos y recreacionales, así como numerosos centros de interés cultural y con las condiciones medio ambientales que hacen atractiva la localidad desde el punto de vista ecológico.

Del estudio de Competitividad del sector turístico emanado por el Ministerio de Desarrollo Económico se puede concluir algunos factores limitantes y oportunidades para este sector en la Ciudad de Pamplona: Las limitantes verdaderamente serias provienen de la inseguridad del territorio rural que impone unos riesgos altos de encuentros con los grupos subversivos tales como retenes, cobro de peajes o incendio de vehículos, dentro de las oportunidades para el desarrollo del 
turismo en Pamplona existe en la recuperación de la antigua vía Pamplona - Duitama, más corta y más lógica que la vía por Bucaramanga para dirigirse a Bogotá y que fuera la ruta secular de conexión entre Bogotá y Caracas.

Los hoteles y residencias existentes en la ciudad y los servicios ofrecidos se detallan en la siguiente tabla.

Tabla 10. Hoteles y residencias de pamplona

\begin{tabular}{|c|c|c|c|c|}
\hline $\begin{array}{c}\text { Nombre } \\
\text { Establecimiento }\end{array}$ & $\begin{array}{l}\text { No } \\
\text { Hab. }\end{array}$ & $\begin{array}{c}\text { No } \\
\text { Camas }\end{array}$ & $\begin{array}{l}\text { Capacidad } \\
\text { (personas) }\end{array}$ & Servicios prestados \\
\hline Casa de Encuentros & 30 & 60 & 80 & Alojamiento \\
\hline Nazareth & & & & Restaurante \\
\hline \multirow[t]{2}{*}{ Hotel Cariongo } & 81 & 164 & 164 & $\begin{array}{l}\text { Alojamiento, Restaurante, } \\
\text { sala de Conferencias, } \\
\text { Parqueadero etc. }\end{array}$ \\
\hline & 50 & 100 & 120 & \\
\hline \multirow[t]{2}{*}{ Hotel Imperial } & & & & $\begin{array}{l}\text { Alojamiento, Restaurante, } \\
\text { Cafetería }\end{array}$ \\
\hline & 31 & 80 & 80 & \\
\hline \multirow[t]{2}{*}{ Hotel Alamo } & & & & $\begin{array}{l}\text { Alojamiento, Restaurante, } \\
\text { Parqueadero }\end{array}$ \\
\hline & 24 & 48 & 50 & \\
\hline \multirow[t]{2}{*}{ Hotel Orsua } & & & & $\begin{array}{l}\text { Alojamiento } \\
\text { Restaurante }\end{array}$ \\
\hline & 11 & 18 & 20 & \\
\hline Hotel Cotranal & & & & $\begin{array}{l}\text { Alojamiento, restaurante } \\
\text { cafetería }\end{array}$ \\
\hline
\end{tabular}


Análisis del estatuto único de rentas del municipio de Pamplona|68

\begin{tabular}{lcccl}
\hline $\begin{array}{c}\text { Nombre } \\
\text { Establecimiento }\end{array}$ & $\begin{array}{c}\text { No } \\
\text { Hab. }\end{array}$ & $\begin{array}{c}\text { No } \\
\text { Camas }\end{array}$ & $\begin{array}{c}\text { Capacidad } \\
\text { (personas) }\end{array}$ & Servicios prestados \\
\hline Hotel Los Llanos & 8 & 18 & 20 & Alojamiento \\
Residencias San & 10 & 17 & 20 & Alojamiento \\
Carlos & 10 & 10 & 15 & \\
Residencias Francis & & & & Alojamiento \\
Residencias & 9 & 15 & 17 & Alojamiento \\
El Prado & & & & \\
\hline
\end{tabular}

Fuente: Cámara de Comercio Pamplona 2001

\section{$\begin{array}{llllllll}\text { OFERTA } & Y & \text { DEMANDA } & \text { (BIENES } & Y & \text { MATERIAS PRIMAS) DE } & \text { LA }\end{array}$ MICROEMPRESA DE PAMPLONA}

En esta unidad se describen la Oferta y la Demanda que los microempresarios de Pamplona sostienen en un mercado de bienes terminados y de insumos o materias primas que se requieren para desarrollar su actividad económica bien sea industrial o comercial. 


\section{- Sector industrial}

Los seis (6) subsectores más representativos en la industria a nivel microempresarial son: Producción de alimentos y bebidas, confección de prendas de vestir, cuero y calzado, muebles de madera, imprentas y metalmecánica.

En este orden, los productos alimenticios que tienen una mayor representatividad en volumen de producción total del subsector son: en primer lugar, los productos de panaderías (bizcochos, galletas, pastelería, etc.) que alcanzan el 55.77\%. En segundo lugar se ubican la producción de carnes y embutidos que representan un $13.46 \%$, en tercer lugar los dulces en general (confites, bocadillos, etc.) que representan el 9.61\%. Otras actividades con buen registro en producción son el procesamiento productos lácteos (kumis, yogurt, quesos, etc.), fabricación de pastas alimenticias (fideos, espaguetis, etc.) y la trilla de café y procesamiento de harinas.

Las materias primas para producir los anteriores artículos, que son en su mayoría insumos primarios como café (grano), leche, carnes, huevos, etc., insumos como harinas, azúcar y grasas son conseguidas a través de distribuidores principalmente de Bucaramanga. Otro sector de importancia en la actividad manufacturera de Pamplona se refiere a la confección de prendas de vestir, donde tiene preponderancia la fabricación e tejidos como suéteres, sacos y abrigos que significan el $67.5 \%$ de la producción de confecciones. Con menor participación en volumen de producción pero con buenas perspectivas de crecimiento están la ropa deportiva y la ropa interior que son especialidades que muestran una tendencia favorable. 
Tabla 11. Principales bienes producidos en pamplona

\begin{tabular}{lc}
\hline \multicolumn{1}{c}{ Línea de Productos } & $\begin{array}{c}\text { Representatividad por línea de } \\
\text { Producción \% }\end{array}$ \\
\hline Suéteres (Tejidos) & 67,5 \\
Ropa Deportiva & 15,0 \\
Ropa Interior & 15,0 \\
Chaquetas & 2,5 \\
\hline \multicolumn{2}{c}{ TOTAL } \\
\hline
\end{tabular}

* Fuente: Cámara de Comercio Pamplona 2001

Los insumos requeridos para estas confecciones como lanas, hilos, telas, hilazas, botones, etc., son conseguidos con equitativa preferencia de los productores, en Bucaramanga, Cúcuta o Bogotá.

Tabla 12. Principales materias primas

\begin{tabular}{cc}
\hline Materia Prima & $\begin{array}{c}\text { Peso Específico de los Insumos } \\
\text { Demandados }\end{array}$ \\
\hline Lana & 55,0 \\
Hilos & 20,0 \\
Tela & 20,0 \\
Hilaza & 2,5 \\
Botones & 2,5 \\
\hline TOTAL & 100,0
\end{tabular}

Fuente: Cámara de Comercio Pamplona 2001

La participación del subsector del calzado es prácticamente nulo ya que sólo existe un taller de este tipo. Solamente se detectó la existencia de una pequeña zapatería artesanal que produce en mínimas cantidades y adquiere sus insumos (cuero, pegante, suelas) en la ciudad de Cúcuta principalmente. 
En lo correspondiente al subsector maderas y muebles, se encontraron productos como muebles para el hogar (sala, comedor y alcoba) que aunque su producción es artesanal, registran buena calidad. Estos muebles son completados con la fabricación de puertas, closets y cocinas que son demandadas para dotación de viviendas en construcción o en remodelación.

Tabla 13. Principales bienes producidos

\begin{tabular}{cc}
\hline Línea de Productos & $\begin{array}{c}\text { Representatividad por línea de } \\
\text { Producción \% }\end{array}$ \\
\hline Muebles Hogar & 30,0 \\
Puertas & 30,0 \\
Closets & 25,0 \\
Cocinas & 15,0 \\
\hline TOTAL & 100,0
\end{tabular}

* Fuente: Cámara de Comercio Pamplona 2001

En cuanto a la procedencia de las materias primas como las maderas, provienen de Saravena. Otros insumos como tablex, triples, fórmica, pinturas y pegantes son adquiridas en Cúcuta o incluso en Venezuela. Sin embargo, existen depósitos de estos materiales en Pamplona que facilitan su consecución en la misma localidad. 
Tabla 14. Principales materias primas

\begin{tabular}{cc}
\hline Materia Prima & $\begin{array}{c}\text { Peso Específico de los Insumos } \\
\text { Demandados }\end{array}$ \\
\hline Madera & 65,0 \\
Tablex, Triplex & 20,0 \\
Fórmica & 7,5 \\
Pintura & 5,0 \\
Pegante & 2,5 \\
\hline TOTAL & 100,0 \\
\hline
\end{tabular}

* Fuente: Cámara de Comercio Pamplona 2001

En cuanto al subsector de imprentas (tipografías y litografías) la oferta de productos se limita a la impresión de talonarios, volates, tarjetería, revistas, edición de libros y encuadernación igualmente la impresión de papelería en general.

Los insumos, papel, tintas, películas son provenientes principalmente de Bucaramanga donde se ubican los más grandes distribuidores de estos materiales para la Región Nororiental del país.

El último subsector, en la parte industrial, es el de metalmecánica que ofrece productos metálicos entre los cuales se destacan las herramientas agrícolas y artículos fabricados mediante la ornamentación como puertas, ventanas, rejas, etc.

Los implementos como el hierro que es el material básico en todas sus formas (varillas, láminas, ángulos, etc.), además del carbón mineral, las soldaduras y pinturas se consiguen en su totalidad mediante depósitos distribuidores de estos materiales en Pamplona. 


\section{- SECTOR COMERCIAL}

Como se mencionó en la descripción general del municipio de Pamplona, la actividad comercial tiene mayor incidencia en la economía del municipio; se tomaron como base las microempresas del comercio al detal de productos clasificados en los subsectores de alimentos, textiles, vestuario, calzado y muebles de madera o metálicos.

El comercio de alimentos agrupa la mayor cantidad de establecimientos representados en tiendas, graneros, bodegas y autoservicios (supermercados), entre otros. En este contexto se comercializan los víveres, abarrotes y demás productos de consumo masivo que se demandan en la canasta familiar y por ende se registran altos índices de rotación de inventarios y de volúmenes de ventas. Estos productos (arroz, panela, azúcar, aceite, rancho, licores, aseo personal, etc.) son adquiridos por estos comerciantes a bodegas de mayor tamaño que funcionan en la misma ciudad, sin embargo, estas bodegas se surten de grandes distribuidores de Cúcuta o de Bucaramanga.

Tabla 15. Principales productos

\begin{tabular}{cc}
\hline PRODUCTO & $\begin{array}{c}\text { PARTICIPACIÓN } \\
\text { PORCENTUAL }\end{array}$ \\
\hline Arroz. & 20.0 \\
Panela. & 18.8 \\
Azúcar. & 12.5 \\
Aceite. & 7.5 \\
Pañales. & 7.5 \\
Comestibles. & 6.3 \\
Pastas. & 5.0 \\
Sal. & 5.0 \\
\hline
\end{tabular}




\begin{tabular}{cc}
\hline PRODUCTO & $\begin{array}{c}\text { PARTICIPACIÓN } \\
\text { PORCENTUAL }\end{array}$ \\
\hline Harina. & 3.8 \\
Leche. & 3.8 \\
Licores. & 3.8 \\
Otros. & 6.3 \\
\hline TOTAL & 100,0 \\
\hline
\end{tabular}

Fuente: Cámara de Comercio Pamplona 2001

Por su parte, el comercio de vestuario y calzado se encuentra como uno de los más dinámicos a cuanto satisfacción de la demanda local, que registran las mayores ventas en las líneas de chaquetas que representa el $25.0 \%$ del total frente a otras líneas como calzado en cuero para mujeres con el $17.5 \%$ entre otros como ropa para dama y caballero, calzado para hombre, calzado deportivo y por último la ropa interior.

Tabla 16. Principales productos

\begin{tabular}{cc}
\hline Materia Prima & $\begin{array}{c}\text { Peso Específico de los Insumos } \\
\text { Demandados }\end{array}$ \\
\hline Chaquetas. & 25,0 \\
Calzado Dama. & 17,5 \\
Calzado Caballero. & 15,0 \\
Ropa Dama. & 14,5 \\
Ropa Caballero. & 13,0 \\
Calzado Deportivo. & 10,0 \\
Ropa Interior. & 5,0 \\
\hline TOTAL & 100,0
\end{tabular}

Fuente: Cámara de Comercio Pamplona 2001

En cuanto a las fábricas que suministran estas mercancías encontramos una participación mayoritaria de las de Bucaramanga seguidas por fábricas de Bogotá, Medellín, Cali y hasta algunas 
de Boyacá. Debemos mencionar la baja participación que registraron las fábricas de confecciones, que significa una baja aceptación de los pamploneses por las prendas de vestir fabricadas en la misma ciudad.

La última actividad comercial se refiere a la venta de muebles y afines donde tienen una buena influencia los fabricantes locales como proveedores de estos almacenes registrando una tercera parte en la participación frente a los productores de muebles de Bucaramanga, Bogotá y Cúcuta. Las principales líneas comercializadas son muebles para el hogar (salas, comedores y alcobas) muebles de oficina (escritorios, sillas, bibliotecas, etc.) y como complemento la línea de colchones.

Tabla 17. Procedencia de los productos

\begin{tabular}{cc}
\hline Ciudad & Participación por Ciudad \% \\
\hline Bucaramanga. & 41,7 \\
Bogotá. & 25,1 \\
Medellín. & 16,6 \\
Cali. & 8,3 \\
Boyacá. & 8,3 \\
\hline TOTAL & 100,0
\end{tabular}

* Fuente: Cámara de Comercio Pamplona 2001

Tabla 18. Principales productos

\begin{tabular}{cc}
\hline Producto & Participación Porcentual \\
\hline Muebles de Oficina. & 33,3 \\
Colchones. & 20,0 \\
Muebles de Hogar. & 46,7 \\
\hline TOTAL & 100,0
\end{tabular}

Fuente: Cámara de Comercio Pamplona 2001 


\subsubsection{Tunja}

Se encuentra ubicada sobre la cordillera Oriental en la parte central del departamento de Boyacá. Su ubicación resulta estratégica por los ejes viales que la interconectan con los Llanos Orientales, la Costa Atlántica y el centro del país (su distancia con Bogotá es de 123 km), además de ser corredor turístico y de la producción de acero del oriente del departamento. Es preciso anotar que el nuevo corredor vial Bogota-Sogamoso, no tiene impacto en la circulación de vehículos dentro de la ciudad -ya que éste no fue trazado por la ciudad, como si lo hacía la antigua vía-, lo que podría reducir los costos de mantenimiento en la malla vial interna urbana, pero asimismo, reducir la importancia de la ciudad como lugar de paso.

Esta ciudad cuenta con una extensión territorial de $121.4 \mathrm{~km} 2$, de los cuales el $87 \%$ corresponde al área rural y el 13\% al área urbana. No obstante, la población del municipio de Tunja se concentra en la cabecera municipal. Es notable el escaso desarrollo urbanístico-arquitectónico de la ciudad, es suficiente una mirada a la distribución de terrenos construidos desordenadamente y dispersos sobre la periferia y a lo largo de la ciudad que contrasta con los enormes terrenos baldíos en el centro; a pesar de contar con centros comerciales, centros educativos y un centro cultural y administrativo, la ciudad reproduce la deficiencia de un ordenamiento en la construcción residencial.

\subsubsection{Actividades económicas de la ciudad de Tunja}


En el Plan de desarrollo 2008-2011 se registran algunas cifras muy sugerentes. Primero, la tasa neta de entrada de empresas (\% de nuevas empresas que entraron en el último año) fue del 11,6\%. Segundo, el índice de densidad industrial (número de establecimientos industriales por $\mathrm{km} 2$ ) fue del 0,06. Tercero, la productividad total de los factores (valor de producción sobre valor de insumos en miles de pesos) fue del $0.72 \%$, donde la dinámica de la productividad total fue del $5.80 \%$, esto en parte por que la eficiencia de los procesos empresariales (valor agregado sobre el valor de insumos) es de 0,34 . Las cifras trabajadas nos permiten afirmar que la ciudad durante los últimos años ha venido fortaleciendo su economía en el sector de los servicios. Pero también los datos del Plan de Desarrollo reconocen la decreciente inversión en el sector agroindustrial y científico-tecnológico que ha derivado en uno de los crecimientos económicos más bajos de las ciudades del país. Tunja se especializa en una línea competitiva específica relacionada con la prestación de servicios en educación, salud y turismo; su ventaja competitiva consiste en la provisión de equipamientos en salud, educación y cultura religiosa que le permite una alta capacitación y formación de sus habitantes, además, su localización geoestratégica le posibilita una relativa afluencia en el intercambio mercantil de la región. 


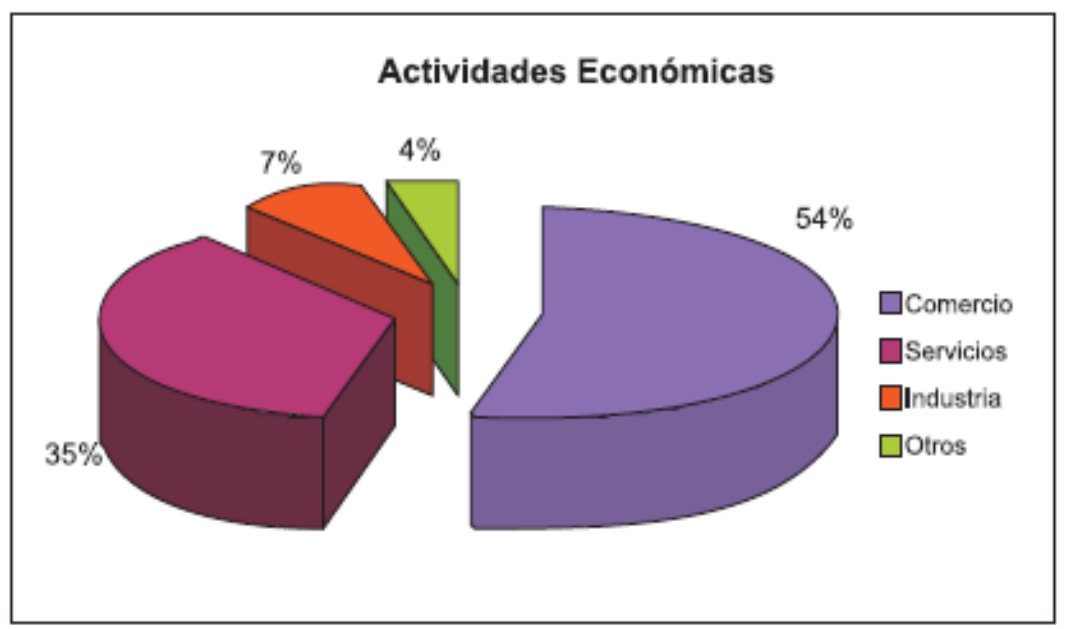

Figura 1. Actividades económicas en Tunja

Fuente: Elaboración plan de desarrollo de Tunja 2008

La ciudad experimentó un deficiente crecimiento en las actividades agropecuarias e industriales. No obstante, su importancia regional es indiscutible desde la perspectiva de la primacía urbana y su localización geoestratégica.

Una revisión preliminar de las cifras que aparecen en el Plan nos permiten realizar tres comentarios muy precisos: a) El comercio significa aproximadamente el 52\% de las actividades económicas de la ciudad; b) Dicho comercio tiene como plataforma central las actividades agropecuarias, la siderúrgica, la turística, y la cultural del departamento de Boyacá; c) adicionalmente, los servicios $(34.73 \%)$ están fuertemente articulados a las actividades ya descritas; d) Tunja al igual que otras capitales de departamento, no cuenta con un sector industrial a gran escala. Las labores empresariales son mayoritariamente en micros, pequeñas y medianas empresas en su mayoría de origen familiar. 
Un factor que cada vez cobra más importancia en la actividad económica gira entorno a la alta prestación en educación superior y salud. A pesar de que Tunja sea una ciudad costosa, la oferta educativa con siete universidades, un instituto SENA y diversas instituciones educativas con programas técnicos y tecnológicos, hacen de ella una ciudad promisoria y competitiva en el aspecto educativo y cultural. Por otra parte, el sector salud cuenta con equipamientos adecuados, personal altamente capacitado y el sector educación con una considerable inversión pública, lo que permite una oferta competitiva sobre dichos sectores.

\subsubsection{Ocaña}

La interacción de los aspectos ambientales, económicos y sociales del territorio constituye la base primordial para establecer el uso, ocupación y aprovechamiento del suelo; además de la caracterización y valoración de los ecosistemas como base para la zonificación ambiental y el establecimiento del uso sostenible de la tierra. Por el oriente limita con el municipio de San Calixto, la Playa y Abrego, por el Norte limita con el municipio de Teorama, Convención y el Carmen por el sur limita con el municipio de Abrego.

Ocaña se encuentra a 203 kilómetros de la ciudad de Cúcuta, y a 299 kilómetros de la ciudad de Bucaramanga- Santander, esta distancia son por vías terrestres.

La ciudad de Ocaña está conformada por tres grandes sectores económicos: (Figura No.1) comercial, manufacturero y de servicios. El sector comercial representa la principal actividad económica con un total de 252 empresas, que participan con el 71\%, seguido del sector servicios 
con un total de 92 empresas, que representa el $26 \%$ y las empresas dedicadas a la actividad manufacturera con un total de 9 empresas que participan con el $3 \%$.

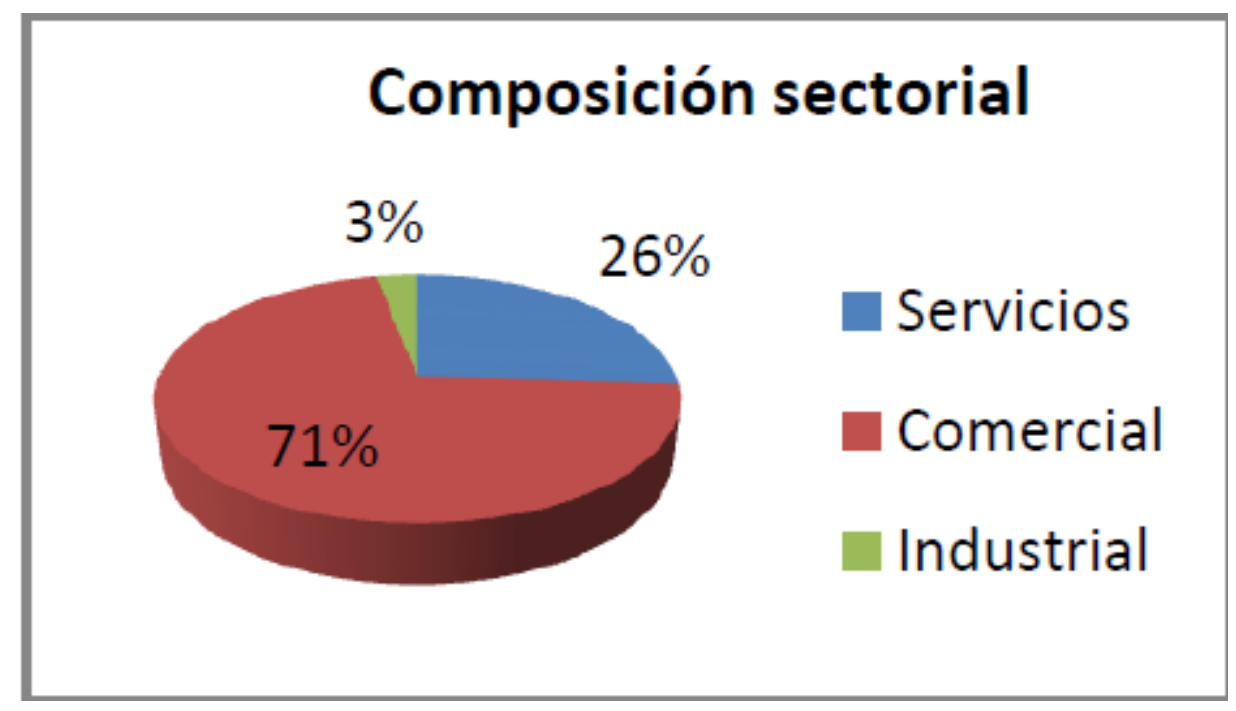

Figura 2. Composición Sectorial Ocaña

Las microempresas representan el $96 \%$ del total de las empresas; mientras que las empresas pequeñas y medianas representan $3 \%$ y $1 \%$, respectivamente. (Figura No.3). En Ocaña, el tejido empresarial se encuentra altamente atomizado, siendo la microempresa su piedra angular. 


\section{Tamaño de las unidades productivas}

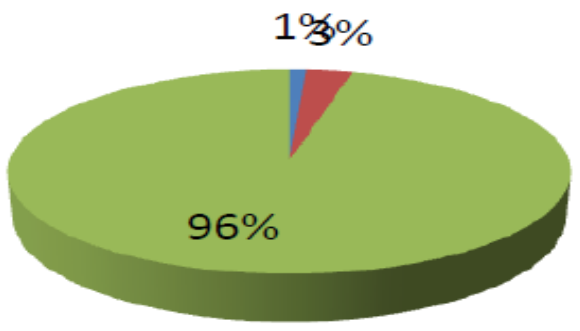

$$
\begin{aligned}
& \text { Mediana } \\
& \text { Empresa } \\
& \text { Pequeña } \\
& \text { Empresa } \\
& \text { Microempresa }
\end{aligned}
$$

Figura 3. Tamaño de las unidades productiva 
Tabla 19. Comparativo tarifas aplicadas en el impuesto de industria y comercio Pamplona, Tunja

\section{y Ocaña}

\begin{tabular}{|c|c|c|c|c|}
\hline & & PAMPLONA & TUNJA & OCAÑA \\
\hline \multicolumn{5}{|c|}{ INDUSTRIALES } \\
\hline & ACTIVIDADES & TARIFA & & \\
\hline & \begin{tabular}{|l} 
INDUSTRIALES (Contempladas Art. Del Presente Estatuto) \\
\end{tabular} & $5 \times 1000$ & & \\
\hline 1.001 & $\begin{array}{l}\text { Producción de alimentos, excepto bebidas, producción de calzado, prendas de vestir y } \\
\text { tejidos. }\end{array}$ & & $4 \times 1000$ & \\
\hline 1.002 & Producción de materiales para construcción. & & $6 \times 1000$ & \\
\hline 1.003 & Fabricación de muebles de madera o metálicos & & $5 \times 1000$ & \\
\hline 1.004 & Fabricación de productos primarios de hierro, acero y materiales de transporte. & & $7 \times 1000$ & \\
\hline 1.005 & Explotación de canteras. & & $6 \times 1000$ & \\
\hline 1.006 & Fabricación de bebidas alcohólicas y sus derivados & & $7 \times 1000$ & \\
\hline 1.007 & Producción de materiales en Chircales & & $4 \times 1000$ & \\
\hline 1.008 & Demás actividades Industriales. & & $7 \times 1000$ & \\
\hline 101 & Actividades Industriales & & & $4 \times 1000$ \\
\hline \multicolumn{5}{|c|}{ COMERCIALES } \\
\hline & Venta y Distribución de Combustibles y derivados de Petróleo & $10 \times 1000$ & & \\
\hline & Venta y Distribución de Cigarrillos y Licores (estancos) & $10 \times 1000$ & & \\
\hline & Demás Actividades Comerciales (Contempladas en el Art. 61 de Presente Estatuto) & $8 \times 1000$ & & \\
\hline & Cooperativas sin ánimo de lucro que realizan actividades comerciales & $2 \times 1000$ & & \\
\hline 2001 & $\begin{array}{l}\text { Comercio de alimentos agrícolas y productos agrícolas en bruto, en establecimientos } \\
\text { especializados. }\end{array}$ & & $7 \times 1000$ & \\
\hline 2002 & Comercio de productos farmacéuticos, medicinales, en establecimientos. & & $8 \times 1000$ & \\
\hline 2003 & $\begin{array}{l}\text { Comercio de productos farmacéuticos, medicinales, en pequeñas droguerías, cuyo } \\
\text { patrimonio inscrito en la Cámara de Comercio no supere los } 6 \text { SMLMV }\end{array}$ & & $5 \times 1000$ & \\
\hline 2004 & $\begin{array}{c}\text { Comercio en supermercados y Droguerías de cadena, comercio de textiles y prendas de } \\
\text { vestir en almacenes de cadena }\end{array}$ & & $10 \times 1000$ & \\
\hline 2005 & $\begin{array}{c}\text { Comercio de vehículos automotores incluídas las motocicletas, comercio de } \\
\text { bicicletas. }\end{array}$ & & $10 \times 1000$ & \\
\hline 2006 & Comercio de combustibles derivados del petróleo para automotores & & $8 \times 1000$ & \\
\hline 2007 & Comercio de gas natural & & $10 \times 1000$ & \\
\hline 2008 & Comercio de conexiones para el gas natural & & $10 \times 1000$ & \\
\hline 2009 & Comercio de energía Eléctrica. Transmisión y Conexión de Energía Eléctrica. & & $10 \times 1000$ & \\
\hline 2010 & Comercio de líneas telefónicas. Comercio de Telefonía Celular. & & $10 \times 1000$ & \\
\hline 2011 & Venta de joyas en establecimientos especializados & & $9 \times 1000$ & \\
\hline 2012 & Venta en supermercados, almacenes de calzado y prendas de vestir. & & $6 \times 1000$ & \\
\hline 2013 & Comercio de Cigarrillos y licores en establecimientos especializados. & & $10 \times 1000$ & \\
\hline 2014 & Comercio en establecimientos minoristas (tiendas de barrio) & & $5 \times 1000$ & \\
\hline 2015 & $\begin{array}{l}\text { Comercio de materiales para construcción, Comercio en ferreterías incluyendo pinturas y } \\
\text { comercio de vidrios. Venta de maderas }\end{array}$ & & $6 \times 1000$ & \\
\hline 2016 & Venta de repuestos para automotores en general. & & $8 \times 1000$ & \\
\hline 2017 & Depósitos de cerveza y gaseosa. & & $10 \times 1000$ & \\
\hline 2018 & Expendios de carnes & & $9 \times 1000$ & \\
\hline 2019 & Comercio de Electrodomésticos, equipos de Oficina, Computadoras, Equipos Médicos. & & $9 \times 1000$ & \\
\hline 2020 & Comercio de Artesanías & & $4 \times 1000$ & \\
\hline 2021 & Comercio de metales minerales y metalíferos en formas primarias & & $8,5 \times 1000$ & \\
\hline 2022 & Comercio en establecimientos Fotográficos o casas fotográficas. & & $9 \times 1000$ & \\
\hline 2023 & Demás actividades comerciales & & $10 \times 1000$ & \\
\hline 201 & Venta de alimentos y productos agrícolas en bruto, venta de textos escolares y libros & & & $3 \times 1000$ \\
\hline $202^{\underline{00}}$ & $\begin{array}{c}\text { Venta de madera y materiales para la construcción, venta de automotores incluida las } \\
\text { motocicletas. Venta de cigarrillos y licores, venta de combustibles }\end{array}$ & & & $5 \times 1000$ \\
\hline 203 & $\begin{array}{c}\text { y derivados de petróleo, venta de joyas, y venta de drogas y medicamentos, compraventas } 0 \\
\text { casas comerciales }\end{array}$ & & & $8 \times 1000$ \\
\hline 204 & Demás actividades comerciales & & & $5 \times 1000$ \\
\hline
\end{tabular}


Análisis del estatuto único de rentas del municipio de Pamplona|83

\begin{tabular}{|c|c|c|c|c|}
\hline \multicolumn{5}{|c|}{ SERVICIOS } \\
\hline & Servicios Públicos & $10 \times 1000$ & & \\
\hline & Servicios de Comunicaciones (Internet-movil-Tv.cable y Suscripción) & $10 \times 1000$ & & \\
\hline & Servicio de casas de empeño y compraventa & $10 \times 1000$ & & \\
\hline & Servicios de restaurantes, estaderos, as aderos y piqueteaderos & $10 \times 1000$ & & \\
\hline & Servicios de billares, casa de juegos, casinos y demás juegos de suerte yazar. & $10 \times 1000$ & & \\
\hline & Servicios de Discotecas, piano bar, tabernas, casas Lenocinio y similares. & $10 \times 1000$ & & \\
\hline & Servicios profesionales constituidos en sociedades de hecho. & $8 \times 1000$ & & \\
\hline & Servicio de Transporte terrestre automotor (Art. 102-2 ley 633 de 2000). & $5 \times 1000$ & & \\
\hline & Servicios de construcción (constructores) & $5 \times 1000$ & & \\
\hline & Servicios de Turismo & $5 \times 1000$ & & \\
\hline & Servicios de Consultorías & $5 \times 1000$ & & \\
\hline & Demás Actividades de Servicios (Contempladas Art. 62 de Estatuto). & $8 \times 1000$ & & \\
\hline 3.001 & $\begin{array}{l}\text { Transporte interdepartamental, Transporte urbano e intermunicipal, transporte escolar, } \\
\text { transporte especial y de carga. }\end{array}$ & & $7 \times 1000$ & \\
\hline 3.002 & Otra clase de Transporte & & $10 \times 1000$ & \\
\hline 3.003 & $\begin{array}{l}\text { Presentación de películas en salas de cine, talleres de reparación, zapatería, peluquería, } \\
\text { carpintería y montallantas. }\end{array}$ & & $4.5 \times 1000$ & \\
\hline 3.004 & Consultoría profesional, servicio de laboratorios clínicos, notarias, curadurías & & $9 \times 1000$ & \\
\hline 3.005 & $\begin{array}{l}\text { Servicios prestados por contratistas de construcción de obras civiles y urbanizadores y } \\
\text { demás de construcción }\end{array}$ & & $6 \times 1000$ & \\
\hline 3.006 & Servicio de Acarreos de valores & & $10 \times 1000$ & \\
\hline 3.007 & Servicio de transporte de trasteos de Muebles y enseres & & $9 \times 1000$ & \\
\hline 3.008 & $\begin{array}{l}\text { Servicio de Salud, servicios prestados por I.P.S., E.P.S. y A.R.S, y demás Entidades } \\
\text { prestadoras de Salud. }\end{array}$ & & $10 \times 1000$ & \\
\hline 3.009 & Servicio de lonchería y cafeterías. & & $5 \times 1000$ & \\
\hline 3.010 & Servicio de clubes sociales & & $9 \times 1000$ & \\
\hline 3.011 & Servicio de Operación de Telefonía. & & $10 \times 1000$ & \\
\hline 3.012 & $\begin{array}{l}\text { Servicio de Telefonía prestados por Agremiaciones Comunales y personas naturales en } \\
\text { S.A.l. }\end{array}$ & & $5 \times 1000$ & \\
\hline 3.013 & Demás servicios de Telefonía. & & $10 \times 1000$ & \\
\hline 3.014 & Servicio de Energía Eléctrica y similares & & $10 \times 1000$ & \\
\hline 3.015 & Servicio de acueducto, alcantarillado, aseo y similares & & $10 \times 1000$ & \\
\hline 3.016 & Servicio de edición de periódicos y revistas, servicios de radio. & & $7 \times 1000$ & \\
\hline 3.017 & Servicio de transmisión de Televisión por cable. & & $10 \times 1000$ & \\
\hline 3.018 & $\begin{array}{l}\text { Servicio de restaurante, asaderos, parqueaderos, hoteles de menos de dos estrellas y } \\
\text { residencias. }\end{array}$ & & $7 \times 1000$ & \\
\hline 3.019 & $\begin{array}{l}\text { Servicios en Servitecas, Agencias de publicidad,Servicios funerarios, Floristerías, } \\
\text { servicios de Auxiliares de Seguros, Servicios de auxiliares de los Fondos de pensiones y } \\
\text { Cesantías, Servicio de auxiliares de la Administración Financiera, Servicio de las } \\
\text { inmobiliarias. Servicio de Arrendamiento en general. }\end{array}$ & & $10 \times 1000$ & \\
\hline 3.020 & $\begin{array}{l}\text { Servicios de vigilancias, servicios de bares, discotecas, hoteles de más de dos estrellas, } \\
\text { moteles, amoblados, casas de lenocinio y casas de empeño. }\end{array}$ & & $10 \times 1000$ & \\
\hline 3.021 & Servicio de Educación Superior. & & $10 \times 1000$ & \\
\hline 3.022 & Servicio de Educación Primaria y Secundaria & & $5 \times 1000$ & \\
\hline 3.023 & Demás actividades de Servicio & & $10 \times 1000$ & \\
\hline 301 & $\begin{array}{l}\text { Servicios de restaurante, cafetería, publicación de revistas, libros y periódicos, } \\
\text { organización de eventos; educación privada, excepto universitaria y técnica, }\end{array}$ & & & $3 \times 1000$ \\
\hline 302 & $\begin{array}{l}\text { Servicios de radiodifusión y producción de televisión, parabólicas o las que se dedique al } \\
\text { usufructo del espacio electromagnético }\end{array}$ & & & $4 \times 1000$ \\
\hline 303 & $\begin{array}{l}\text { Consultoría profesional, tipografías, transporte, servicios prestados por contratistas de } \\
\text { construcción, constructores y urbanizadores. }\end{array}$ & & & $5 \times 1000$ \\
\hline 303 & $\begin{array}{l}\text { Servicios de Bar, grill, discoteca y similares; servicios de hotel, motel, hospedaje, } \\
\text { amoblados y similares; servicio de vigilancia, servicios públicos domiciliarios; servicios } \\
\text { de televisión y televisión por cable o satelital, telefonía móvil celular. }\end{array}$ & & & $5 \times 1000$ \\
\hline 304 & Demás actividades de servicios & & & $5 \times 1000$ \\
\hline
\end{tabular}




\begin{tabular}{|c|c|c|c|c|}
\hline \multicolumn{5}{|c|}{ SECTOR FNANCIERO } \\
\hline & Compañía de seguros de vida, seguros generales, reaseguros & $5 \times 1000$ & \multirow{3}{*}{$\begin{array}{c}\text { Los ingresos } \\
\text { obtenidos por } \\
\text { rendimientos } \\
\text { financieros, } \\
\text { tributarán } \\
\text { con la tarifa } \\
\text { correspondiente } \\
\text { a la actividad } \\
\text { principal que } \\
\text { desarrolle el } \\
\text { contribuyente. }\end{array}$} & \\
\hline & Compañías de financiamiento comercial & $5 \times 1000$ & & \\
\hline & Las demás entidades financieras permitidas por la Ley & $5 \times 1000$ & & \\
\hline 400 & Entidades Financieras & & & $8 \times 1000$ \\
\hline
\end{tabular}

Fuente: Elaboración Propia

Según el Acuerdo 027 del 10 de Diciembre de 2005, modificado por el acuerdo 042 diciembre del 2013, el Municipio de Pamplona establece unos límites de las tarifas para el impuesto de industria y comercio que son:

De dos a siete por mil ( $2-8 \times 1000)$ mensual por actividades industriales, y De dos al diez por mil $(2-10 \times 1000)$ mensual para actividades comerciales y de servicios.

Como se puede observar para las actividades industriales el Municipio de Pamplona maneja una tarifa única del 5 X 1000, donde se consideran actividades industriales para ellos las dedicadas a la producción, extracción, fabricación, confección, preparación, transformación, reparación, manufactura y ensamblaje de cualquier clase de materiales o bienes, el Municipio de Tunja maneja un rango de tarifas que va del 4 x 1000 al 7 x 1000, donde clasifica las actividades y según la misma se define su tarifa, el Municipio de Ocaña igualmente que el Municipio de Pamplona maneja una única tarifa que es del 4 x 1000. 
Teniendo en cuenta las tarifas mencionadas consideramos que es favorable manejar una única tarifa para todas las actividades industriales, esto con el fin de que traiga beneficios económicos también a la población en el desarrollo de sus actividades y que esto al contrario traiga para ellos un incentivo de poder contribuir con el Municipio y no al tener tantas tarifas según la actividad no sea posible que paguen adecuadamente sus tributos por confusiones en el manejo de tarifas.

En las actividades comerciales encontramos que el Municipio de Pamplona maneja un rango de tarifas que va del 2 x 1000 que son de las Cooperativas sin ánimo de lucro hasta un 10 x 1000 que es venta y distribución de combustibles y las demás actividades comerciales que se entienden, las destinadas al expendio, compraventa o distribución de bienes o mercancías, tanto al por mayor como al por menor, y las demás definidas como tales por el Código de Comercio siempre y cuando no estén consideradas por el mismo código o por este estatuto, como actividades industriales o de servicios maneja una tarifa del 8x1000.

El Municipio de Tunja encontramos que su rango es del 4 x 1000 que es el comercio de Artesanías hasta un 10 x 1000 que es comercio de gas natural y energía eléctrica, igualmente se puede observar que Tunja en la Actividad Comercial de productos derivados del petróleo maneja una tarifa inferior que el Municipio de Pamplona que maneja una tarifa del 10 x 1000, sería importante que el Municipio de Pamplona pudiera disminuir esa tarifa teniendo en cuenta que es un Municipio intermedio entre dos Ciudades como lo es Bucaramanga y Cúcuta y muy cercano a la frontera con Venezuela, esto con propósito de incentivar más la venta de combustible. 
El Municipio de Ocaña maneja un rango del 3 x 1000 al 8 x 1000, donde podemos ver que al igual que el Municipio de Tunja maneja una misma tarifa para la actividad de comercio de productos derivados del petróleo.

En las Actividades de servicios en el Municipio de Pamplona maneja unos rangos que van del 5 X 1000 al 10 X 1000, en donde observamos, que son tarifas muy elevadas, ya que se maneja en los servicios de hoteles el 8 x 1000 y de restaurantes del 10 x 1000, teniendo en cuenta que es un Municipio universitario y este servicio lo consumen más los estudiantes, por eso es importante nivelar las tarifas de tal manera que se eliminen los Restaurantes informales y se pueda generar más empleo formal y abierto para más consumidores, el Municipio de Tunja maneja unas tarifas del 4,5 x 1000 al 10 x 1000, donde en los servicios de restaurante y Hospedajes maneja una tarifa más baja que en Comparación con el Municipio de Pamplona del 7 x 1000 y el Municipio de Ocaña maneja para estas actividades una tarifa del 5 x 1000, ya que igual que los demás Municipios son sectores universitarios y por tanto estos servicios son más utilizados por estudiantes por eso la importancia de manejar unas tarifas más bajas para que esto se vea reflejado en sus consumidores.

En el sector Financiero el Municipio de Pamplona maneja una tarifa única del 5 x 1000, el Municipio de Tunja define que Los ingresos obtenidos por rendimientos financieros, tributarán con la tarifa correspondiente a la actividad principal que desarrolle el contribuyente. Y el Municipio de Ocaña maneja una tarifa única del 8 x 1000. 


\section{IMPUESTO AVISOS Y TABLEROS}

El artículo 37 de la ley 14 de 1983 dispuso que el impuesto de avisos y tableros se liquidara y cobrara, en forma complementaria con el impuesto de industria y comercio; sin embargo no todos los sujetos pasivos del impuesto de industria y comercio, son responsables del impuesto complementario de avisos y tableros.

Para determinar la responsabilidad en el impuesto de avisos y tableros, es necesario que concurran dos condiciones, primero se debe tener la calidad de sujeto pasivo del impuesto de industria y comercio y segundo mediante avisos y tableros colocados en el espacio público o espacios privados visibles desde el espacio público, se difunda el nombre comercial, se acredite su actividad económica, su establecimiento, sus productos o servicios. 
Tabla 20. Comparativos impuesto vallas, avisos y tableros Pamplona, Tunja y Ocaña

PAMPLONA

SEGÚN LA

\section{LEY}

TUNJA

OCAÑA
ART 93 TARIFAS

IMPUESTO DE VALLAS, AVISOS Y TABLEROS

1, La tarifa aplicable al impuesto complementario de avisos y tableros será del quince por ciento $(15 \%)$ sobre el valor del impuesto de industria y comercio liquidado en el período

2. Las tarifas del Impuesto a la Publicidad exterior visual fijadas en proporción directa al área de cada valla son las siguientes:

\section{DIMENSIONES}

TARIFAS

Hasta Ocho (8) Mt 20.5 SMMLV por año Mayor de ocho (8) y hasta doce (12) Mts $21 \quad$ SMMLV por año.
Artículo 25. Base gravable y Tarifa. Se liquidará como complemento del impuesto de industria $\mathrm{y}$ comercio, tomando como base el impuesto a cargo total de industria $\mathrm{y}$ comercio a la cual se aplicará una tarifa fija del $15 \%$.
ARTICULO 144. ARTÍCULO 84. TARIFAS. Las vallas TARIFA. La tarifa con área superior a 2 corresponde al quince metros cuadrados e por ciento $(15 \%)$ del inferior a 8 metros valor del Impuesto de cuadrados pagarán una Industria y Comercio. tarifa de 5 salarios Parágrafo. El mínimos mensuales impuesto de Avisos y legales vigentes, tableros se causa sin proporcional al área de perjuicio del cada una de las vallas Impuesto de Vallas o instaladas. publicidad exterior Las vallas con área visual igual o superior a 8 metros cuadrados TAMAÑNO DE LAS pagarán una tarifa VALLAS equivalente a 5 salarios mínimos mensuales TARIFA legales vigentes.

TAMAÑNO DE LAS 3 smmlv por año VALLAS

TARIFAS Vallas de $10 . \mathrm{m} 2$ o mas. $5 \mathrm{smmlv}$ por año

Vallas de 2 a 8 M2 5

Mayor de doce (12) y hasta veinte (20) Mts 22 SMMLV por año. smmlv por año

proporcional al Vallas en vehículos automotores con 


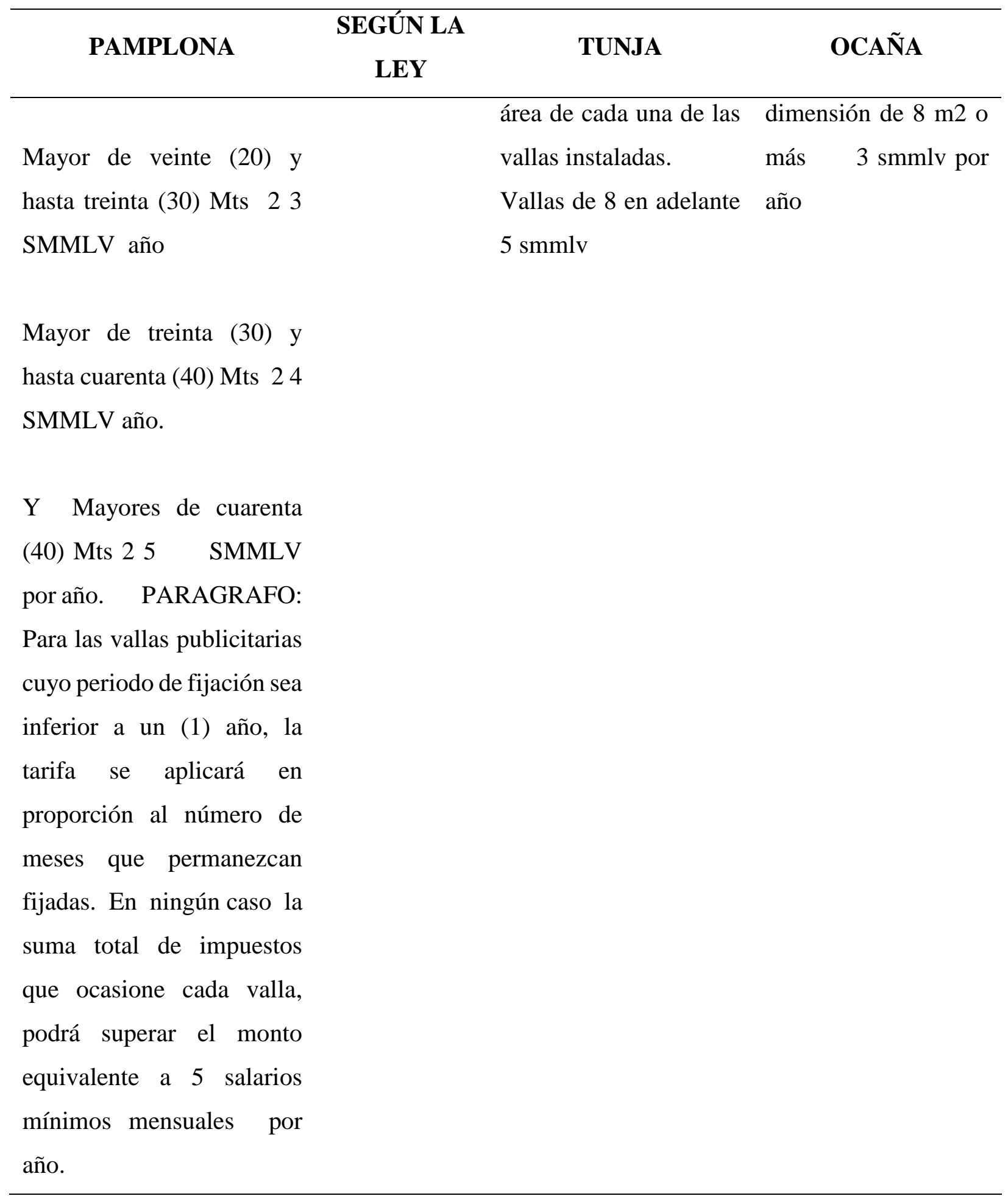

Fuente: Elaboración Propia 
Las tarifas aplicadas para las vallas, Avisos y Tableros Pamplona estableció una tarifa del $15 \%$ sobre el valor del impuesto de Industria y Comercio y para las tarifas del Impuesto de Publicidad se definen por metros cuadrados, igualmente que el Municipio de Ocaña, mientras que Tunja maneja las tarifas dependiendo únicamente los metros cuadrados de las vallas.

Tabla 21. Comparativo según los ingresos presupuestados con lo recaudado

\begin{tabular}{|c|c|c|c|c|}
\hline \multicolumn{5}{|c|}{ COMPARATIVO PRESUPUESTADO -RECAUDADO } \\
\hline PRESUPUESTADO & 2012 & 2013 & 2014 & 2015 \\
\hline 01-Impuesto Predial Unificado Vigencias -Presupuestado & $1,500,000,000$ & $1,650,000,000$ & $1,630,000,000$ & $1,500,000,000.00$ \\
\hline \multirow[t]{2}{*}{ RECAUDADO } & $1,228,864,610$ & $1,256,775,001$ & $1,388,180,832$ & $1,268,083,614.60$ \\
\hline & $271,135,390$ & $393,224,999$ & $241,819,168$ & $231,916,385$ \\
\hline 01-Impuesto Predial Unificado años anteriores & $300,000,000$ & $335,000,000$ & $411,200,000$ & $500,000,000.00$ \\
\hline \multirow[t]{2}{*}{ RECAUDADO } & $221,837,549$ & $416,109,563$ & $493,352,343$ & $493,004,243.00$ \\
\hline & $78,162,451$ & $-81,109,563$ & $-82,152,343$ & $6,995,757$ \\
\hline 01-Impuesto de industria y comercio vigencias & $585,000,000$ & $650,000,000$ & $700,000,000$ & $900,000,000.00$ \\
\hline \multirow[t]{2}{*}{ RECAUDADO } & $598,403,941$ & $441,057,245$ & $928,013,287$ & $789,112,739.74$ \\
\hline & $-13,403,941$ & $208,942,755$ & $-228,013,287$ & $110,887,260$ \\
\hline 01-Impuesto de industria y comercio años anteriores & $60,000,000$ & $75,000,000$ & $35,000,000$ & $20,000,000.00$ \\
\hline \multirow[t]{2}{*}{ RECAUDADO } & $22,449,414$ & $17,333,332$ & $20,507,911$ & $36,399,874.00$ \\
\hline & $37,550,586$ & $57,666,668$ & $14,492,089$ & $-\quad 16,399,874$ \\
\hline 01-Impuesto de avisos y tableros & $100,000,000$ & $70,000,000$ & $75,000,000$ & $90,000,000.00$ \\
\hline \multirow[t]{2}{*}{ RECAUDADO } & $90,925,147$ & $55,585,502$ & $87,229,723$ & $91,817,810.00$ \\
\hline & $9,074,853$ & $14,414,498$ & $-12,229,723$ & $1,817,810$ \\
\hline 01-AVISOS Y TABLEROS VIGENCIAS ANTERIORES & & $30,000,000$ & $25,000,000$ & $2,000,000.00$ \\
\hline \multirow[t]{2}{*}{ RECAUDADO } & & $2,551,330$ & 729,508 & $5,061,904.00$ \\
\hline & & $27,448,670$ & $24,270,492$ & $3,061,904$ \\
\hline & & & & \\
\hline
\end{tabular}

Fuente: Elaboración Propia 


\section{Conclusiones}

En la investigación se desarrolló ampliamente la base teórica referente a los principios constitucionales, tributos, hecho imponible, exenciones y exoneraciones, ordenanzas. La Constitución de la República de Colombia, la Ley de Régimen Municipal y su Reglamento y las Ordenanzas Municipales, este análisis, se le realizo a los Municipios de Pamplona, Ocaña y Tunja, con la finalidad de realizar un comparativo, teniendo en cuenta que son Municipios Estudiantiles y Culturalmente parecidos, para analizar su forma de recaudar los impuestos y poder analizar el impacto de cada Municipio.

El Secretario de Hacienda del Municipio de Pamplona, tiene mucho sentido de pertenencia hacia su Municipio lo que se constituye en una fortaleza importante, además cuentan con suficiente recurso humano en esta dependencia, el problema es que no buscan nuevas alternativas para mejorar el sistema tributario vigente, esto tiene su origen en el desconocimiento que puedan tener sobre la labor que realizan, por eso es indispensable tener en cuenta que declaraciones no generan recaudo en los diferentes impuestos, ya que esto es un desgaste Administrativo para el Municipio y a su vez para los Contribuyentes.

Existe un número significativo de contribuyentes aproximadamente un $20 \%$ que vienen presentando la declaración de Industria y Comercio basados en la tarifa mínima, esto debido a que no hay una desagregación adecuada de las mismas. 
Como podemos observar en los últimos 2 años, los ingresos presupuestados, según lo recaudado, en el impuesto de Predial Unificado de las Vigencias actuales, ha tenido un buen recaudo según el año 2014, el recaudo fue de $85 \%$ según lo presupuestado, y en el año 2015 fue del $84 \%$, lo que significa que existe un adecuado manejo en la recaudación de los impuesto, el porcentaje faltante, se puede manifestar por desconocimiento de la norma, o por dificultad en el pago.

En el Impuesto de Industria Y Comercio según los 2 años, 2014-2015 se manifiesta un incremento en la Recaudación, de un 32,57\%, lo que muestra que existió una sensibilización adecuada, a la comunidad para ponerse al día en sus obligaciones, pagando estás a tiempo, a pesar de que el Municipio no se acogió a la nueva reforma tributaria ley 1739 del 2014, este aumento también se atribuye en gran parte a las obras que se han venido ejecutando en el Municipio de Pamplona, con recursos del DPS, FONADE y el Sistema General de Regalías.

En el Impuesto de avisos y tableros en el año 2014 se manifiesta un incremento de $16 \%$, donde se ve el incremento de la publicidad legal, donde puede ser por la creación de nuevas empresas o la legalización de las ya existentes. Y en el año 2015, un 2\%, lo que declara una buena ejecución en la recaudación.

En las vigencias anteriores también podemos observar una buena recaudación en los impuestos de Predial Unificado, Industria y Comercio, y Avisos y Tableros, en donde el Municipio 
de Pamplona tiene un personal capacitado encargado exclusivamente de los cobros coactivos, para recuperar cartera de las vigencias anteriores. 


\section{RECOMENDACIONES}

Con la finalidad de dar continuidad al trabajo realizado se formulan las siguientes recomendaciones:

Los funcionarios de la Dirección de Administración Municipal deben ser sensibilizados acerca de la importancia de crear nuevos acuerdos, actualizar las existentes, y poner en práctica los procesos de recaudación y fiscalización de manera eficiente, a través de cursos de actualización y perfeccionamiento en materia de Hacienda Municipal.

Elaborar un censo de contribuyentes en el Municipio de Pamplona, para verificar que todos los establecimientos estén inscritos en el Registro de Contribuyentes e incitar a los que aún no forma parte de dicho registro al cumplimiento de su obligación tributaria.

Actualizar los acuerdos existentes en el Municipio y activar las que no se están aplicando. En dicha actualización deberán tomarse en cuenta aspectos tales como: Integración de incentivos fiscales en las exoneraciones, exenciones y rebajas, para estimular la inversión dentro del Municipio, así como para los contribuyentes que cumplen de manera responsable con sus obligaciones tributarias.

Establecer en los acuerdos el control fiscal y administrativo de manera clara y sencilla, permitiendo cumplir con los procesos de fiscalización administrativos sancionatorios, con la aplicación de multas, cierres temporal y definitivo y revocatoria de la licencia si fuere el caso. 
Iniciar una campaña de divulgación de los acuerdos Municipales, a través de los medios de comunicación como prensa, radio y televisión, incentivando la cultura tributaria y el sentido de pertenencia al Municipio.

Es evidente la necesidad de actualizar los acuerdos existentes y elaborar las que no se están aplicando, mediante la introducción de incentivos fiscales que actúen como fuente de atracción del contribuyente Análisis del estatuto único de rentas del municipio de Pamplona. 


\section{Referencias}

\section{Referencias}

Acuerdo 027. de Diciembre 31 de 2009. Por medio del cual se adopta el estatuto único de rentas para el municipio de Pamplona. obtenido de Acuerdo 42, Por el cual se adopta el estatuto tributario del municipio de Ocaña. obtenido de http://pamplona-nortedesantander.gov.co/apc-aafiles/61386164343338313235643530653061/acuerd-027-estatuto-de-rentas-2007-modicado-por-acuerdo041-7-_1.pdf

Acuerdo 027. de Diciembre 10 de 2005. Por medio del cual se adopta el Estatuto Unico de Rentas para el Municipio de Pamplona. obtenido de http://pamplona-nortedesantander.gov.co/apc-aafiles/61386164343338313235643530653061/acuerd-027-estatuto-de-rentas-2007-modicado-por-acuerdo041-7-_1.pdf

Birg, R., Poterra, J., \& Slemron, J. (2006). Bases de una Reforma Estructural. Bogota.

Decreto 389. (2006). de Diciembre 29 de 2006. Por medio del cual se ordena y renumera el Estado de Rentas del Municipio de Tunja compilando en un solo cuerpo juridico la totalidad de la normatividad tributaria del Municipio de Tunja. obtenido de http://www.tunja-boyaca.gov.co/apc-aafiles/63353630666563646636613430366433/Decreto_0389_29Dic2006_Estatutos_Rentas.pdf

Diario Oficial (1993). Decreto Ley 1421 de Julio 22 de 1993. "Por el cual se dicta el régimen especial para el Distrito Capital de Santafé de Bogotá". N (40.958). obtenido de http://www.alcaldiabogota.gov.co/sisjur/normas/Norma1.jsp?i=9027

Garcia peña, M. (2008). Bogota.

Diario Oficial (1983). Ley 14 de Julio 6 de 1983. Por la cual se fortalecen los fiscos de las entidades territoriales y se dictan otras disposiciones $\mathrm{N}^{\circ}$ (36.288). obtenido de http://www.alcaldiabogota.gov.co/sisjur/normas/Norma1.jsp?i=267

Diario Oficial (2010). Ley 1430 de Diciembre 29 de 2010. Por medio de la cual se dictan normas tributarias de control y para la competitividad. $\mathrm{N}^{\circ}$ (47937). obtenido de http://www.alcaldiabogota.gov.co/sisjur/normas/Norma1.jsp?i=41063

Diario Oficial (1996). Ley 299 de Julio 26 de 1996. Por la cual se protege la flora colombiana, se reglamentan los jardines botánicos y se dictan otras disposiciones. $\mathrm{N}^{\circ}$ (42.845) obtenido de http://www.alcaldiabogota.gov.co/sisjur/normas/Norma1.jsp?i=5518

Diario Oficial (1913). Ley 4 , de Octubre 6 de 1913. Sobre régimen político y municipal. $N^{\circ} 15012$. obtenido de http://www.consejodeestado.gov.co/documentos/biblioteca/libros/201314/libro/libro.pdf

Diario Oficial. (1987). Ley 43 Noviembre 30 de 1987. por la cual se regulan varios aspectos de la Hacienda Pública en materia de presupuesto, crédito público interno y externo, impuestos directos e indirectos, se conceden y precisan unas facultades extraordinarias, se establece una inversión forzosa y se dictan otras disposiciones. $\mathrm{N}^{\circ}$ (38.136). obtenido de ftp://ftp.camara.gov.co/camara/basedoc/ley/1987/ley_0043_1987.html

Diario Oficial. (1990). Ley 44 de Diciembre 18 de 1990. por la cual se dictan normas sobre catastro e impuestos sobre la propiedad raíz, se dictan otras disposiciones de carácter tributario, y se conceden unas facultades extraordinarias. $\mathrm{N}^{\circ}$ (39.607). obtenido de http://www.alcaldiabogota.gov.co/sisjur/normas/Norma1.jsp?i=283

Diario Oficial. (1993). Ley 47 de Febrero 19 de 1993. por la cual se dictan normas especiales para la organización y el funcionamiento del Departamento Archipiélago de San Andrés, Providencia Y Santa Catalina. N $^{\circ}$ (40763). obtenido de http://www.alcaldiabogota.gov.co/sisjur/normas/Norma1.jsp?i=2780

Diario Oficial. (1981). Ley 56 de Septiembre 10 de 1981. por la cual se dictan normas sobre obras públicas de generación eléctrica, y acueductos, sistemas de regadío y otras y se regulan las expropiaciones y servidumbres de los bienes afectados por tales obras. $\mathrm{N}^{\circ}$ (35.856). obtenido de https://www.minminas.gov.co/documents/10180/670382/Ley56de1981.pdf/7431ad3d-dcbf-4f1b-9a3d$20 \mathrm{e} 949 \mathrm{c} 30954$

Diario Oficial. (2001). Ley 675 de Agosto 4 de 2001. por medio de la cual se expide el régimen de propiedad horizontal. $\left.\mathrm{N}^{\circ} 844.509\right)$. obtenido de http://www.secretariasenado.gov.co/senado/basedoc/ley_0675_2001.html 
Diario Oficial. (1993). Ley 99 de Diciembre 22 de 1993. por la cual se crea el Ministerio del Medio Ambiente, se reordena el Sector Público encargado de la gestión y conservación del medio ambiente y los recursos naturales renovables, se organiza el Sistema Nacional Ambiental, SINA, y se dictan otras disposiciones. $\mathrm{N}^{\circ}$ (41146). obtenido de http://www.alcaldiabogota.gov.co/sisjur/normas/Norma1.jsp?i=297

Restrepo, J. (2006). Editor Bogota, Hacienda Publica, 6a ed Universidad Externando de Colombia.

Santos, J. M. (2006). Bases para una Reforma Estructural en Colombia, Banco de la Respublica y Fedesarrollo Bogota. 


\section{Apéndices}

\section{Apéndice A: Referentes Legales}

“Art. 338 de la Constitución Nacional, En tiempo de paz, solamente el Congreso, las asambleas departamentales y los concejos distritales y municipales podrán imponer contribuciones fiscales o parafiscales. La ley, las ordenanzas y los acuerdos deben fijar, directamente, los sujetos activos y pasivos, los hechos y las bases gravables, y las tarifas de los impuestos. La ley, las ordenanzas y los acuerdos pueden permitir que las autoridades fijen la tarifa de las tasas y contribuciones que cobren a los contribuyentes, como recuperación de los costos de los servicios que les presten o participación en los beneficios que les proporcionen; pero el sistema y el método para definir tales costos y beneficios, y la forma de hacer su reparto, deben ser fijados por la ley, las ordenanzas o los acuerdos. Las leyes, ordenanzas o acuerdos que regulen contribuciones en las que la base sea el resultado de hechos ocurridos durante un período determinado, no pueden aplicarse sino a partir del período que comience después de iniciar la vigencia de la respectiva ley, ordenanza o acuerdo."

“Art. 362 de la Constitución Nacional” Los bienes y rentas tributarias o no tributarias o provenientes de la explotación de monopolios de las entidades territoriales, son de su propiedad exclusiva y gozan de las mismas garantías que la propiedad y renta de los particulares. Los impuestos departamentales y municipales gozan de protección constitucional y en consecuencia la ley no podrá trasladarlos a la Nación, salvo temporalmente en caso de guerra exterior.” 


\section{“Art. 313 de la Constitución Nacional” Corresponde a los concejos:}

1. Reglamentar las funciones y la eficiente prestación de los servicios a cargo del municipio.

2. Adoptar los correspondientes planes y programas de desarrollo económico y social y de obras públicas.

3. Autorizar al alcalde para celebrar contratos y ejercer pro tempore precisas funciones de las que corresponden al Concejo.

4. Votar de conformidad con la Constitución y la ley los tributos y los gastos locales.

5. Dictar las normas orgánicas del presupuesto y expedir anualmente el presupuesto de rentas y gastos.

6. Determinar la estructura de la administración municipal y las funciones de sus dependencias; las escalas de remuneración correspondientes a las distintas categorías de empleos; crear, a iniciativa del alcalde, establecimientos públicos y empresas industriales o comerciales y autorizar la constitución de sociedades de economía mixta.

7. Reglamentar los usos del suelo y, dentro de los límites que fije la ley, vigilar y controlar las actividades relacionadas con la construcción y enajenación de inmuebles destinados a vivienda. 
8. Elegir Personero para el período que fije la ley y los demás funcionarios que ésta determine.

9. Dictar las normas necesarias para el control, la preservación y defensa del patrimonio ecológico y cultural del municipio.

10. Las demás que la Constitución y la ley le asignen. “

“Art. 287, de la Constitución Nacional, Las entidades territoriales gozan de autonomía para la gestión de sus intereses, y dentro de los límites de la Constitución y la ley. En tal virtud tendrán los siguientes derechos:

1. Gobernarse por autoridades propias.

2. Ejercer las competencias que les correspondan.

3. Administrar los recursos y establecer los tributos necesarios para el cumplimiento de sus funciones.

4. Participar en las rentas nacionales. “

“Art. 169 de la Ley 4 de 1913, son atribuciones de los consejos... 2). Los actos del congreso de carácter general se denominan leyes; los de las asambleas departamentales, ordenanzas, y los 
de los concejos, acuerdos. Los primeros rigen en todo el país; los Segundos en el respectivo departamento, y los últimos, en el correspondiente municipio.”

“Art. 171 de la Ley 4 de 1913, es prohibido a los consejos... 9). Gravar objetos ya gravados por la nación o por el departamento, salvo que se les conceda especialmente el derecho de hacerlo en un caso determinado"

“Art. 11 de la Ley 50 de 1984, Cuando las entidades a que se refiere el Art. 39, numeral 2, literal d) de la Ley 14 de 1983 realicen actividades Industriales o comerciales serán sujetas del impuesto de industria y comercio en lo relativo a tales actividades."

“Art. 62 de la Ley 55 de 1985, Para efectos de la correcta liquidación y pago del impuesto de industria y comercio, los concejos municipales expedirán los acuerdos que garanticen el efectivo control y recaudo del mencionado impuesto."

“Art 47 de la Ley 43 de 1987, Autorizase a los Concejos Municipales y al Concejo del Distrito Especial de Bogotá, para establecer a título de anticipo del impuesto de industria y comercio, una suma hasta de cuarenta por ciento (40\%) del monto del impuesto determinado por los contribuyentes en la liquidación privada, la cual deberá cancelarse dentro de los mismos plazos establecidos para el pago del respectivo impuesto.

Este monto será descontable del impuesto a cargo del contribuyente en el año o período gravable siguiente." 


\section{Apéndice B, Ley 14 DE 1983:}

\section{CAPITULO II, IMPUESTO DE INDUSTRIA Y COMERCIO}

“Artículo 32.- El Impuesto de Industria y Comercio recaerá, en cuanto a materia imponible, sobre todas las actividades comerciales, industriales y de servicio que ejerzan o

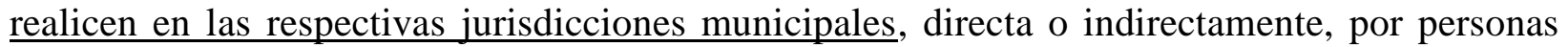
naturales, jurídicas o por sociedades de hecho, ya sea que se cumplan en forma permanente u ocasional, en inmuebles determinados, con establecimientos de comercio o sin ellos. Él texto subrayado fue declarado EXEQUIBLE por la Corte Constitucional, mediante Sentencia C-121 de $2006 "$

“Artículo 33'.- El Impuesto de Industria y Comercio se liquidará sobre el promedio mensual de ingresos brutos del año inmediatamente anterior, expresados en moneda nacional y obtenidos por las personas y sociedades de hecho indicadas en el artículo anterior, con exclusión de: Devoluciones ingresos proveniente de venta de activos fijos y de exportaciones, recaudo de impuestos de aquellos productos cuyo precio esté regulado por el Estado y percepción de

subsidios. Ver Concepto 498/23.09.96. Dirección de Impuestos Distritales. Impuestos Distritales. CJA12201996 Concepto No. 551/11.03.97. Dirección de Impuestos Distritales. CJA12451997 
Sobre la base gravable definida en este artículo se aplicará la tarifa que determinen los Concejos Municipales dentro de los siguientes límites:

1. Del dos al siete por mil (2-7 x 1.000) mensual para actividades industriales, y

2. Del dos al diez por mil $(2-10$ x 1.000$)$ mensual para actividades comerciales y de servicios.

Los municipios que tengan adoptados como base del impuesto los ingresos brutos o ventas brutas podrán mantener las tarifas que en la fecha de la promulgación de esta Ley hayan establecido por encima de los límites consagrados en el presente artículo.

Parágrafo $1^{\circ}$.- Derogado por el art. 22, Ley 50 de 1984. Para la aplicación de lo dispuesto en el presente artículo los Concejos Municipales expedirán los acuerdos respectivos antes del 30 de septiembre de 1984.

Parágrafo $2^{\circ}$.- Las Agencias de Publicidad, Administradoras y Corredoras de Bienes Inmuebles y Corredores de Seguros, pagarán el Impuesto de que trata este artículo sobre el promedio mensual de ingresos brutos entendiendo como tales el valor de los honorarios, comisiones y demás ingresos propios percibido para sí.

Parágrafo $3^{\circ}$.- Los distribuidores de derivados del petróleo pagarán el impuesto de que trata el presente artículo sobre el margen bruto fijado por el Gobierno para la comercialización de los combustibles. 
NOTA: Este artículo se encuentra incorporado en el art. 196 del Decreto Nacional 1333 de 1986 (Código de Régimen Municipal)

Artículo $\mathbf{3 4}^{\mathbf{0}}$.- Para los fines de esta Ley, se consideran actividades industriales las dedicadas a la producción, extracción, fabricación, confección, preparación, transformación, reparación, manufactura y ensamblaje de cualquier clase de materiales o bienes.

Artículo ${35^{\circ}}^{\circ}$ - Se entienden por actividades comerciales, las destinadas al expendio, compraventa, o distribución de bienes o mercancías, tanto al por mayor como al por menor, y las demás definidas como tales por el Código de Comercio siempre y cuando no estén consideradas por el mismo Código o por esta Ley, como actividades industriales o de servicios. Él texto subrayado fue declarado EXEQUIBLE por la Corte Constitucional, mediante Sentencia C-121 de 2006

Artículo $\mathbf{3 6}^{\mathbf{0}}$.- Son actividades de servicios las dedicadas a satisfacer necesidades de la comunidad mediante la realización de una o varias de las siguientes o análogas actividades: expendio de bebidas y comidas; servicio de restaurante, cafés, hoteles, casas de huéspedes, moteles, amoblados, transporte y aparcaderos, formas de intermediación comercial, tales como el corretaje, la comisión, los mandatos y la compra - venta y administración de inmuebles; servicios de publicidad, interventoría, construcción y urbanización, radio y televisión, clubes sociales, sitios de recreación, salones de belleza, peluquerías, portería, servicios funerarios, talleres de reparaciones eléctricas, mecánica, automoviliarias y afines, lavado, limpieza y teñido, salas de cine y arrendamiento de películas y de todo tipo de reproducciones que contengan audio 
y vídeo, negocios de montepíos y los servicios de consultoría profesional prestados a través de sociedades regulares o de hecho.

Artículo $3^{\circ}$.- El impuesto de avisos y tableros, autorizado por la Ley 97 de 1913 y la Ley 84 de 1915, se liquidará y cobrará en adelante a todas las actividades comerciales, industriales y de servicios como complemento del impuesto de industria y comercio, con una tarifa de un quince por ciento (15\%) sobre el valor de éste, fijada por los Concejos Municipales.

Artículo 38 ${ }^{\circ}$.- Los municipios sólo podrán otorgar exenciones de impuestos municipales por plazo limitado, que en ningún caso excederá de diez años, todo de conformidad con los planes de desarrollo municipal.

Artículo 39.- No obstante lo dispuesto en el artículo anterior continuarán vigentes:

1. Las obligaciones contraídas por el Gobierno en virtud de tratados o convenios internacionales que haya celebrados en el futuro, y las contraídas por la Nación, los Departamentos o los Municipios, mediante contratos celebrados en desarrollo de la legislación anterior.

2. Las prohibiciones que consagra la Ley 26 de 1904; además, subsisten para los Departamentos y Municipales las siguientes prohibiciones:

a. La de imponer gravámenes de ninguna clase o denominación a la producción primaria, agrícola, ganadera y avícola, sin que se incluyan en esta prohibición las fábricas de productos 
alimenticios o toda industria donde haya un proceso de transformación por elemental que ésta sea;

b. La de gravar los artículos de producción, transformación por elemental que esta sea;

c. La de gravar con el impuesto de Industria y Comercio la explotación de canteras y minas diferentes de sal, esmeraldas y metales preciosos, cuando las regalías o participaciones para el municipio sean iguales o superiores a lo que corresponderá pagar por concepto del impuesto de Industria y Comercio;

d. La de gravar con el impuesto de Industria y Comercio, los establecimientos educativos públicos, las entidades de beneficencia, las culturales y deportivas, los sindicatos, las asociaciones de profesionales y gremiales sin ánimo de lucro, los partidos políticos y los hospitales adscritos o vinculados al sistema nacional de salud; Ver Concepto No. 485/12.07.96. Dirección Impuestos Distritales. Impuestos Distritales. CJA12151996

e. La de gravar la primera etapa de transformación realizada en predios rurales cuando se trate de actividades de producción agropecuaria, con excepción de toda industria donde haya una transformación por elemental que ésta sea;

f. La de gravar las actividades del Instituto de Mercadeo Agropecuario, Idema; 